\title{
NEW COMBINATIONS, RANK CHANGES, AND NOMENCLATURAL AND TAXONOMIC COMMENTS IN THE VASCULAR FLORA OF THE SOUTHEASTERN UNITED STATES. II
}

\author{
${ }^{1}$ Alan S. Weakley, ${ }^{2}$ Derick B. Poindexter, \\ ${ }^{3}$ Richard J. LeBlond, ${ }^{4}$ Bruce A. Sorrie, \\ ${ }^{5}$ Cassandra H. Karlsson, ${ }^{6}$ Parker J. Williams \\ UNC Herbarium (NCU), Campus Box 3280, North Carolina \\ Botanical Garden, University of North Carolina at Chapel Hill, \\ C.B. 3280, Chapel Hill, North Carolina 27599-3280, U.S.A. \\ weakley@unc.edu,poindexter@unc.edu, \\ richardleblond@charter.net, basorrie@gmail.com, \\ cassykar@gmail.com,parkerwill93@yahoo.com
}

${ }^{8}$ Steve L. Orzell

Avon Park Air Force Range 29 South Blvd.

Avon Park, Florida 33825, U.S.A. steve.orzell@us.af.mil

${ }^{10}$ Andrea Weeks

Ted R. Bradley Herbarium (GMUF)

George Mason University

Department of Biology

4400 University Drive, MSN $3 E 1$

Fairfax, Virginia 22030, U.S.A. aweeks3@gmu.edu

${ }^{12}$ María Flores-Cruz

División de Ciencias Biológicas y de la Salud

Departamento de Biología

Universidad Autónoma Metropolitana Mexico City, MEXICO

mafc@xanum.uam.mx

${ }^{14}$ George D. Gann

The Institute for Regional Conservation

100 East Linton Blvd, Suite 302B

Delray Beach, Florida 33483, U.S.A.

gann@regionalconservation.org

\author{
${ }^{7}$ Edwin L. Bridges \\ Botanical and Ecological Consultant \\ 5904 72nd Ave, NW \\ Gig Harbor, Washington 98335, U.S.A. \\ ebridges1@gmail.com
}

\author{
${ }^{9}$ Brian R. Keener \\ University of West Alabama (UWAL) \\ Dept. of Biological \& Environm. Sci. Stat. 7 \\ Livingston, Alabama 35470, U.S.A. \\ bkeener@uwa.edu
${ }^{11}$ Richard D. Noyes
Department of Biology
180 Lewis Science Center
University of Central Arkansas
Conway, Arkansas 72035, U.S.A.
rnoyes@uca.edu

\section{${ }^{13}$ James T. Diggs}

University of North Georgia

Gainesville, Georgia

3820 Mundy Mill Road

Oakwood, Georgia 30566, U.S.A.

james.diggs@ung.edu

${ }^{15}$ Aaron J. Floden

Missouri Botanical Garden (MO)

4344 Shaw Blvd

Saint Louis, Missouri 63110, U.S.A

afloden@mobot.org

ABSTRACT

As part of ongoing efforts to understand and document the flora of the southeastern United States, a number of taxonomic changes at generic, specific, and infraspecific rank are made. We also discuss and clarify the recommended taxonomy for other taxa (not requiring nomenclatural acts) and present a point of view about the practical and philosophic basis for making taxonomic changes in an allegedly well-understood flora. The genera (and families) affected are Allium (Alliaceae), Erigeron, Liatris, and Trilisa (Asteraceae), Calycanthus (Calycanthaceae), Gaylussacia (Ericaceae), Dalea and Mimosa (Fabaceae), Hydrophyllum (Hydrophyllaceae), Didymoglossum (Hymenophyllaceae), Monarda (Lamiaceae), Kosteletzkya and Sida (Malvaceae), Narthecium (Nartheciaceae), Agalinis, Melampyrum, and Orobanche/Aphyllon/Myzorrhiza (Orobanchaceae), Dichanthelium and Elymus (Poaceae), Clematis (Ranunculaceae), and Maianthemum (Ruscaceae).

\section{RESUMEN}

Como parte de los esfuerzos en marcha para entender y documentar la flora del sureste de Estados Unidos, se hace un número de cambios taxonómicos en los rangos genéricos, específico, e infraspecífico. También discutimos y clarificamos la taxonomía recomendada para otros 
taxa (que no requieren cambios nomenclaturales) y presentamos un punto de vista de la base práctica y filosófica para hacer cambios taxonómicos en una flora que está bien entendida. Los géneros (y familias) afectados son Allium (Alliaceae), Erigeron, Liatris, y Trilisa (Asteraceae), Calycanthus (Calycanthaceae), Gaylussacia (Ericaceae), Dalea y Mimosa (Fabaceae), Hydrophyllum (Hydrophyllaceae), Didymoglossum (Hymenophyllaceae), Monarda (Lamiaceae), Kosteletzkya y Sida (Malvaceae), Narthecium (Nartheciaceae), Agalinis, Melampyrum, y Orobanche/Aphyllon/Myzorrhiza (Orobanchaceae), Dichanthelium y Elymus (Poaceae), Clematis (Ranunculaceae), y Maianthemum (Ruscaceae)

As part of ongoing work on the Flora of the Southern and Mid-Atlantic States (Weakley 2015; Weakley 2017), as well as for general floristic, conservation, and scientific work in eastern North America, it is necessary or desirable to document the taxonomy being followed. In some cases, new combinations are needed to accurately reflect current taxonomic understanding. Some of these changes are rank changes, while others are generic transfers to allow use of new (or re-adoption of old) generic concepts that are not fully reflected in available nomenclature at the specific or infraspecific levels. Also included are pieces to "clean up" various nomenclatural issues and clarify characters and identification of difficult groups in the regional flora.

Any effort to compile a flora (the book) describing the flora (the set of taxa) for a region involves the reassessment of previous taxonomies that have been applied, along with synthesis of new information. It is surprising how little has been written about this synthetic process, the complications involved, and best practices that might be employed. Weakley (2005) studied "Change over time in our understanding of the flora of the southeastern United States: implications for plant systematics, bioinformatics, and conservation," and one of his findings was that in the southeastern United States (SEUS) flora, the course of taxonomic inquiry was one of essentially "alpha taxonomy" (to 1900, only very sparse and patchy exploration of the SEUS flora had been done up to that time), followed by a phase of splitting (1900-1950), a phase of lumping (1950-1991), then leading to a new phase of splitting (1991-present). While some of these changing trends can be related to advancement of scientific techniques and/or changing concepts of how to apply various taxonomic ranks (family, genus, species, subspecies, variety), many of the trends seem to merely reflect "scientific fashion" (such as the proposed shift from variety to subspecies as the primary infraspecific rank) or the philosophical idiosyncrasies of a particular worker-John Kunkel Small's "if you can recognize it, it's a species" (J.K. Small, pers. comm. to Rogers McVaugh, ca. 1933; R. McVaugh pers. comm. to Weakley, 2005; see Weakley [2005], p. 2942).

Each floristic author is faced with reassessing the taxonomic status quo of previous floristic authors, considering the accumulation of new and old monographs and other taxonomic papers, and when alternate taxonomic opinions have been expressed, weighing the evidence supporting the differing points-of-view.

Here we present a second paper of taxonomic changes, nomenclatural changes, and comments on the taxonomy of SEUS plants, similar to Weakley et al. (2011). Weakley (in prep.) discusses the philosophy and suggested best practices we have tried to follow here, but a summary of our approach is presented in an abstracted form below.

Modern species concepts. We have tried to re-evaluate the flora of the SEUS in the light of modern concepts, emphasizing evolutionary lineages and the degree of their separation from sister lineages. Morphology, molecular phylogenies, ecology, phenology, cytology, and information from other disciplines can all provide evidence useful to the task of evaluating evolutionary lineages. Taxonomic decisions made 50 or 100 years ago with different philosophical underpinning need re-evaluation and re-interpretation; they cannot be accepted without explicit comparison to modern concepts.

Taxonomy should be based on the totality of evidence. We use all techniques and types of evidence we can to make the best decisions we can now. Ecology, biogeography, phenology, cytology, and other information, as available, pertains to the task. Molecular evidence is no silver bullet, and still requires just as much interpretation from all available evidence in order to make best possible taxonomic decisions.

Rank is not based on magnitude of morphological difference. We reject the idea that taxonomic recognition or rank should be based on the magnitude of morphologic difference (microscopic characters = variety, macroscopic $=$ species).

"Flatter" taxonomy is more stable than erecting trinomials and quadrinomials to show alleged relationships. Use of infraspecific ranks, especially the use together of subspecies and variety as quadrinomials to 
try to reflect hypotheses of complex relationships, creates unstable nomenclature as additional data and interpretations accumulate. We are also cautious of the use of infraspecific taxa to group together putative relatives as a "complex," when the entities sometimes warrant higher (species) rank by modern species concepts.

The variety of varieties. We make two uses of the rank of variety. 1. Variety by determination of good evidence. Evidence suggests that there is imperfect evolutionary separation of two entities, which however are supported by sufficient weight of evidence to be evolutionarily diverging lineages. There is often known intergradation in areas of geographic overlap. 2. Variety as a minimum-rank "holding category," in circumstances when evidence is too poor to warrant clear decision-making as to the appropriate rank (species or variety), but there is enough evidence available to be confident that a taxon warrants recognition at variety rank at least. While various and variant usage of varietal rank is not an ideal practice for clarity of intention and communication, it has been done widely by the community without acknowledgment, and we prefer to draw explicit attention to the practice.

Variety vs. subspecies. We here use variety as the primary infraspecific rank. Despite claims of a theoretical difference in meaning between subspecies and variety, in practice the two ranks have no effectively different meaning (Weakley 2005). Variety has been the traditional and long-utilized infraspecific rank in plants. Conversion of all taxa in the SEUS currently treated as subspecies to variety, which are best treated at infraspecific rank based on current data and interpretation, would involve hundreds of new combinations. There are better uses of time and energy.

"Show your work." Hundreds of taxonomic decisions (lumps, splits, rank changes up and down) in the SEUS flora have been made with no explanation, evidence, or rationale provided. For instance, Radford et al. (1968), the most influential manual of the last 50 years in the SEUS, made hundreds of lumping decisions of taxa recognized by Fernald (1950) or Small (1933), but with absolutely no rationale provided (and no bibliography!). Scientific reassessment of such decisions means starting over.

Incrementalism and the urgency of taxonomic progress. We explicitly embrace "taxonomic incrementalism." There is often a temptation to wait for a complete and thorough study of a group, or not to publish good or excellent work that is incremental in order to make it perfect. We encourage advancing taxonomic understanding in the scientific tradition of publishing results (with "work shown") to make incremental progress and to engender rejoinder and follow-up in the research community. The urgency of understanding and conserving our imperiled flora is great, while the capacity of our community is inadequate; we advance faster with synergistic effort.

Primary authorship of the sections in this paper is as follows: Allium (DBP, ASW, \& PJW), Erigeron (DBP, BRK, \& RDN), Liatris (ELB \& SLO), Trilisa (ELB \& SLO), Calycanthus (ASW), Gaylussacia (BAS), Dalea (JTD \& ASW), Mimosa (ASW \& MFC), Hydrophyllum (CHK, ASW, \& DBP), Monarda (AJF), Didymoglossum (GDG \& ASW), Kosteletzkya (AW), Sida (ASW \& DBP), Narthecium (ASW \& BAS), Agalinis (BAS), Melampyrum (AW), Myzorrhiza (ASW), Dichanthelium (RJL), Elymus (DBP \& ASW), Clematis (BRK), and Maianthemum (AJF).

\section{ALLIACEAE (OR AMARYLLIDACEAE S.L.)}

ALLIUM: A new and narrowly endemic onion in the Brushy Mountains of North Carolina

The genus Allium has been the focus of many cytogenetic, morphologic, taxonomic, and phylogenetic studies (Ownbey \& Aase 1956; McNeal \& Jacobsen 2002; Choi \& Cota-Sánchez 2010; Wheeler 2011; \& Celep et al. 2012, to name a few). Wheeler's (2011) work arguably provides our best molecular phylogenetic inference for North American subclades within the genus, yet many questions regarding taxonomy are still apparent. Allium taxonomy in the last half century has shown a troubling trend of lumping morphologically and biogeographically distinctive entities in the SEUS that in our opinion warrant recognition, such as Allium allegheniense Small and A. oxyphilum Wherry, re-recognized by Weakley (2015) and others. While the size and complexity of the genus have discouraged careful species-level inquiry, the A. cernuum/stellatum complex and the A. canadense complex certainly need new attention to provide a reasonable taxonomy that reflects biological reality in the SEUS. We here offer a minor contribution to the "onion problem." 
Wheeler's (2011) phylogenetic analyses indicate that the diploid species Allium cuthbertii Small, is strongly supported as sister to Allium canadense L., a cytogenetically complex species containing both diploid and tetraploid races. As mentioned in Weakley (2015), a peculiar form of A. cuthbertii has been known from 12-15 sites in thin soil mats of rich granitic domes of the Brushy Mountains of Alexander and Wilkes cos., North Carolina. These populations are consistently more robust than typical for the species and always present a distinctly pink perianth (Fig. 1). In addition, these populations are disjunct approximately $220 \mathrm{~km}$ to the north of the distribution of other populations of A. cuthbertii, and are found in thin soils over granitic substrate, unlike the typical populations which are predominately found in less edaphically unique sandy soils of the Coastal Plain (Small 1903, 1933). They demonstrate the same diploid chromosome number as the more widespread type of the species ( $n=7$, counted for this paper). Likewise, other characteristics in these isolated populations differ from the typical populations, including larger seeds with a more distinctly dimpled surface (Fig. 2), larger capsules (Fig. 3), and spathe bracts 5-10-veined (vs. 5-7).

The Brushy Mountain granite domes are biogeographically interesting and support other narrow endemic and notable disjunct plants. Hypericum radfordiorum Weakley ex J. Allison was only named in 2011, but had been repeatedly noted as "unusual" starting in 1940 (Allison 2011). The moss Lewinskya keeverae (H.A. Crum \& L.E. Anderson) F. Lara, Garilleti, \& Goffinet was originally named in 1956 (in the genus Orthotrichum); its unusual features are highlighted by Vitt (2014) and its evolutionary relationships are established as being with a group of (in North America) almost exclusively Rocky Mountain and Pacific Northwest taxa (Vitt 2014; Lara et al. 2016). Other disjuncts on the Brushy Mountain domes are also notably species of Ozarkian/midwestern, more broadly western North American, or even southwestern United States/Mexican affinities: Anemone berlandieri Pritz., Arabis pycnocarpa M. Hopkins, Corydalis micrantha (Engelm.ex A. Gray) A. Gray s.s., and Pellaea wrightiana Hook.

Although the morphological distinctions are not of great magnitude, they are multiple, involve flowers (perianth color), seeds (size and texturing), capsules (size), and vegetative features (stem height and diameter), are well-correlated with one another, and also additionally strongly correlated with disjunct distributions and different habitats of the two putative taxonomic entities. We therefore conclude that species rank is most appropriate. This species adds to the Allium canadense alliance another narrowly distributed, diploid, edaphic specialist (i.e. Allium speculae Ownbey \& Aase) (Ownbey \& Aase 1959).

Allium keeverae D.B. Poind., Weakley, \& P.J. Williams, sp. nov. (Fig. 4). Type: U.S.A. North Carolina: Alexander Co.: soil pits, Rocky Face Mt., granite outcrop 5 mi N of Hiddenite, J.F. Matthews, L. Kesler, J.W. Taylor, P. Campbell s.n. (HоLоTYPE: NCU!; ISOTYPES: BRY, CLEMS, KE, MEM, MISS, MUR, UNCC, USMS, UTC, VSC, WCUH).

Diagnosis.-Differing from Allium cuthbertii in its more robust habit (stems 3-7.5 mm wide vs. 1.5-3.8 mm wide at $1 \mathrm{~cm}$ above the bulb; stems 4-8 dm tall vs. 1.5-5.1 dm tall), perianth medium pink (vs. white or very pale pink), larger capsules, larger and somewhat rugose-dimpled seeds (2.4-3.0 mm vs. $1.8-2.0 \mathrm{~mm}$ ), and disjunct distributions (granite domes of the Brushy Mountains in the nw. Piedmont of North Carolina vs. Coastal Plain and e. Piedmont of South Carolina south through Georgia to ne. Florida and sc. Alabama). Differing from A. canadense var. mobilense in its tepals 7-9(-10) mm, spreading to strongly reflexed (vs. 4-6[-7] and ascending in A. canadense var. mobilense), capsules with contorted apical processes (vs. lacking these), and seeds rugose-dimpled (vs. not dimpled). See Figures 1-4.

Description (modified from FNA description of A. cuthbertii to apply to A. keeverae).—Bulbs usually solitary, without basal bulbels, ovoid, 1-2.1 × 1-1.4 cm; outer coats enclosing single bulb, grayish, reticulate, cells finemeshed, open, fibrous; inner coats whitish, cells vertically elongate, regular. Leaves persistent, withering by anthesis, 2-4, sheathing; blade solid, flat, linear, 12-35 cm $\times 3-6 \mathrm{~mm}$, margins entire or denticulate. Scape persistent, solitary, erect, terete or $\pm 3-4$-angled, $40-80 \mathrm{~cm} \times 3-7.5 \mathrm{~mm}$. Umbel persistent, erect, loose, 10-85-flowered, hemispheric-globose, bulbils unknown; spathe bracts persistent, 2-3, 5-10-veined, lanceolate, \pm equal, apex acuminate. Flowers \pm stellate; tepals $7-9(-10) \mathrm{mm}$, spreading to reflexed at maturity, medium-dark pink, lanceolate, \pm equal, remaining thin and becoming strongly reflexed in fruit, margins entire, apex acuminate; stamens included; anthers yellow; pollen yellow; ovary conspicuously crested; processes 6 , central, irregularly contorted; style linear, equaling stamens; stigma capitate, unlobed or obscurely 3-lobed; 


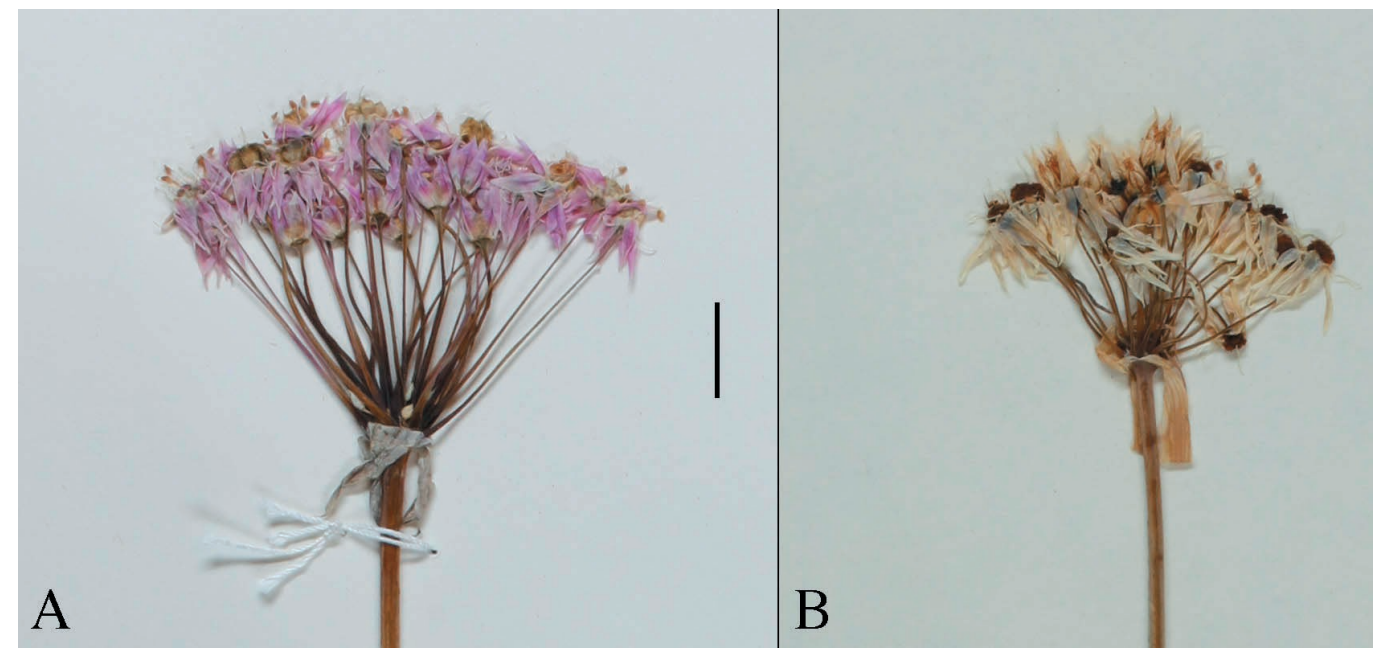

FIG. 1. Inflorescences of A) Allium keeverae (Heiney s.n., NCU; cultivated from Brushy Mountain populations) and B) Allium cuthbertii (Burbanck 1510, $\mathrm{NCU}$; DeKalb (o., GA). Scale bar $=1 \mathrm{~cm}$.
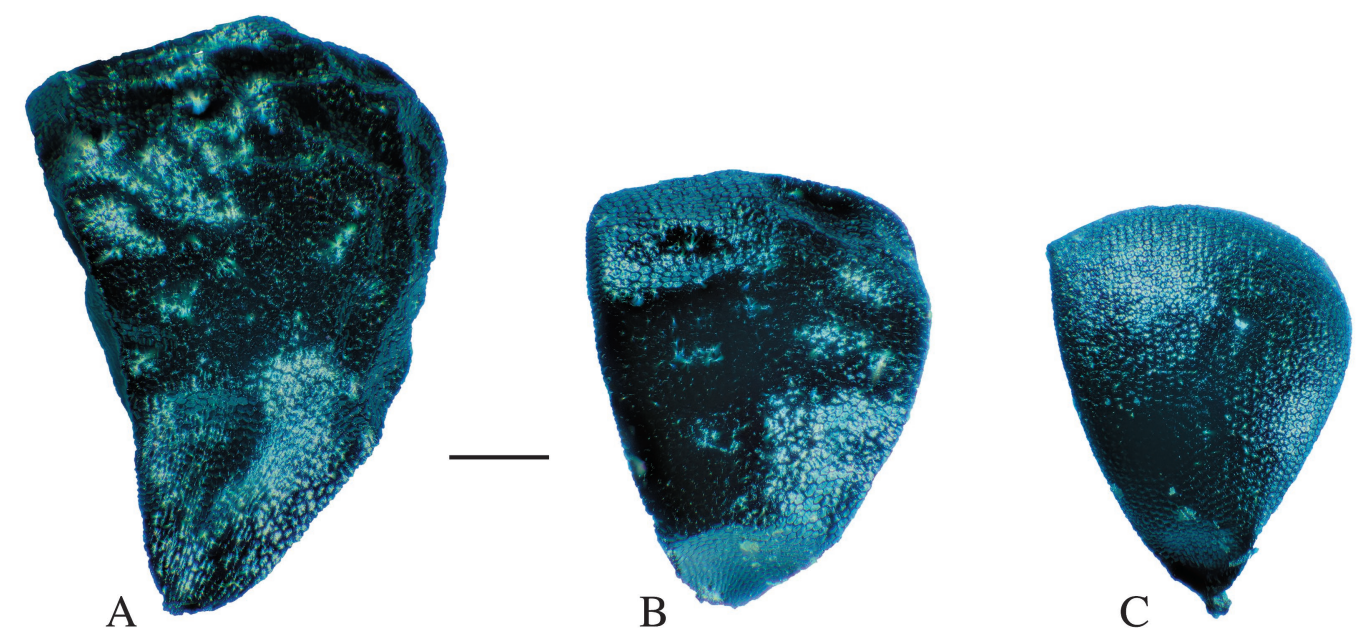

Fig. 2. Seeds of A) Allium keeverae (Radford 13878, NCU; Alexander Co., NC), B) A. cuthbertii (Radford 5354, NCU; Richmond Co., GA), and C) A. canadense var. mobilense (Jones 1032, NCU; Sumter C0., AL). Scale $=0.5 \mathrm{~mm}$.

pedicel 14-45 mm. Seed 2.4-2.7(-3.0) $\mathrm{mm}$, coat shining, rugose-dimpled; cells each with obscure, central papilla. $2 n=14$. Flowering May-early Jun. On granitic outcrops of Piedmont; 300-600 m; Brushy Mountains of N.C. (Alexander and Wilkes counties).

Conservation.-The newly named taxon is of conservation concern, as a very narrow endemic to shallow soil mats on generally south-facing granitic dome faces in the Brushy Mountains of Alexander and Wilkes counties, NC. Few of its sites are under conservation ownership and management. Its NatureServe ranking is G2.

Etymology.-The specific epithet honors the pioneering ecologist, Catherine Keever (1908-2003), who 


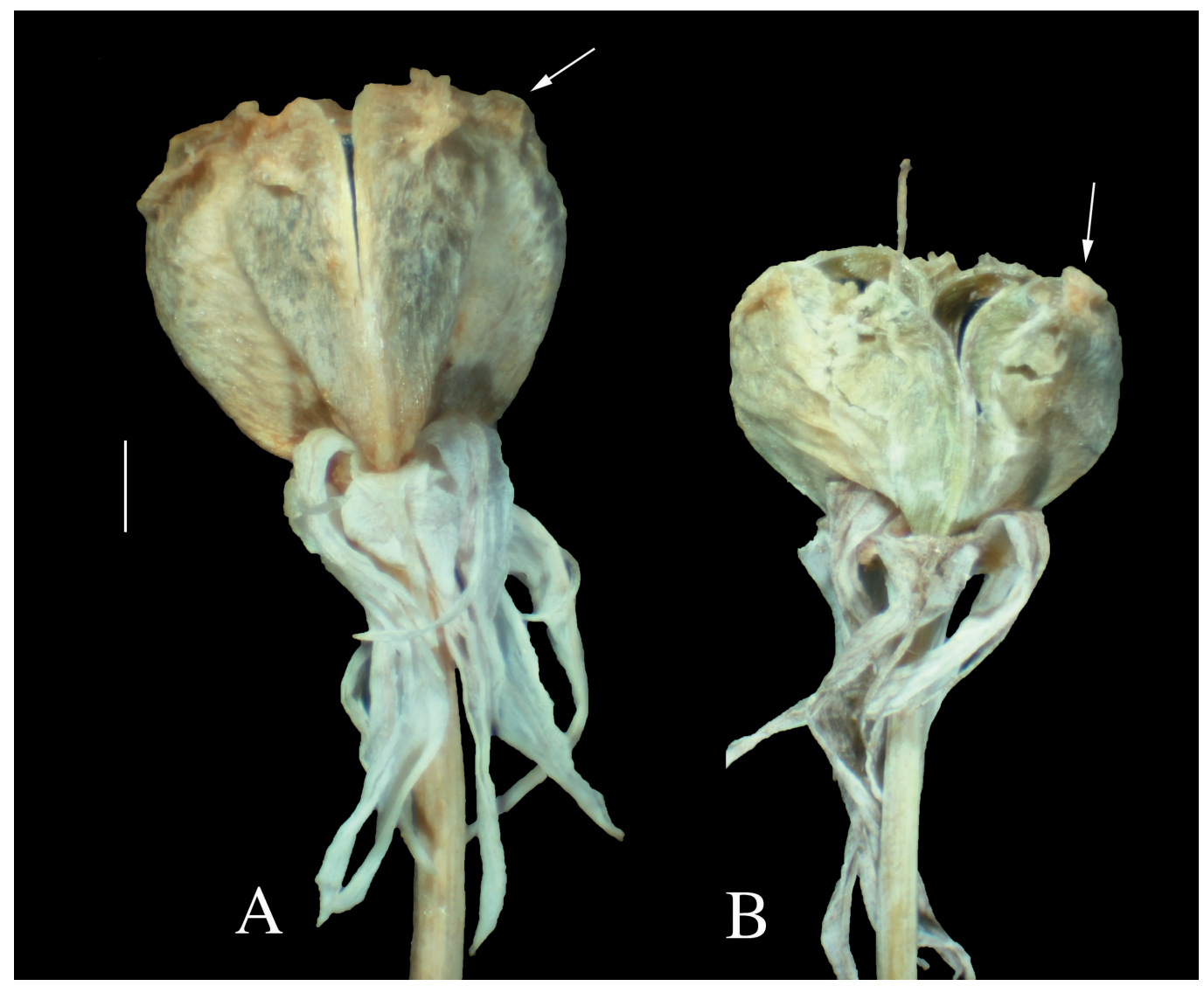

FIG. 3. Capsules of A) Allium keeverae (Radford 13878, NCU; Alexander Co., NC) and B) Allium cuthbertii (Kral 62155, USCH; Lee Co., AL). Arrows indicating contorted ovary processes. Scale $=1 \mathrm{~mm}$.

first worked on the biodiversity of the Brushy Mountains, before going on to contribute greatly to our understanding of ecological succession in the SEUS, as well as other SEUS ecological questions (Keever 1950; Keever et al. 1951; Quarterman \& Keever 1962; Keever 1983). She was also memorialized in the memorable article subtitle "Catherine Keever-you were right!" (McCormick \& Platt 1980). Another Brushy Mountains endemic (since found at a single site in Virginia) was also named for her: Lewinskya keeverae (H.A. Crum \& L.E. Anderson) F. Lara, Garilleti, \& Goffine (originally named in Orthotrichum). The senior author of this paper (ASW) had the honor of visiting the Brushy Mountain granite domes with her on May 1, 1989, and seeing both Lewinskya keeverae and the then-undescribed Allium keeverae.

Although Alliaceae is included in Amaryllidaceae by APG IV (Angiosperm Phylogeny Group 2016), Seberg et al. (2012) and others provide data and interpretations that make a strong case for the benefits of recognizing smaller families in the Asparagales, a course followed here.

\section{ASTERACEAE}

ERIGERON: Elevation of two sexual diploids in the Erigeron strigosus complex to species rank The Erigeron strigosus Muhl. ex. Willd. complex comprises both apomictic polyploids and sexual diploid populations (Noyes \& Groff 2011). Adding to this complexity is recent research demonstrating ploidy-level reduction (dihaploidy) within the genus (Noyes \& Wagner 2014). Apomictic polyploids demonstrate complex 


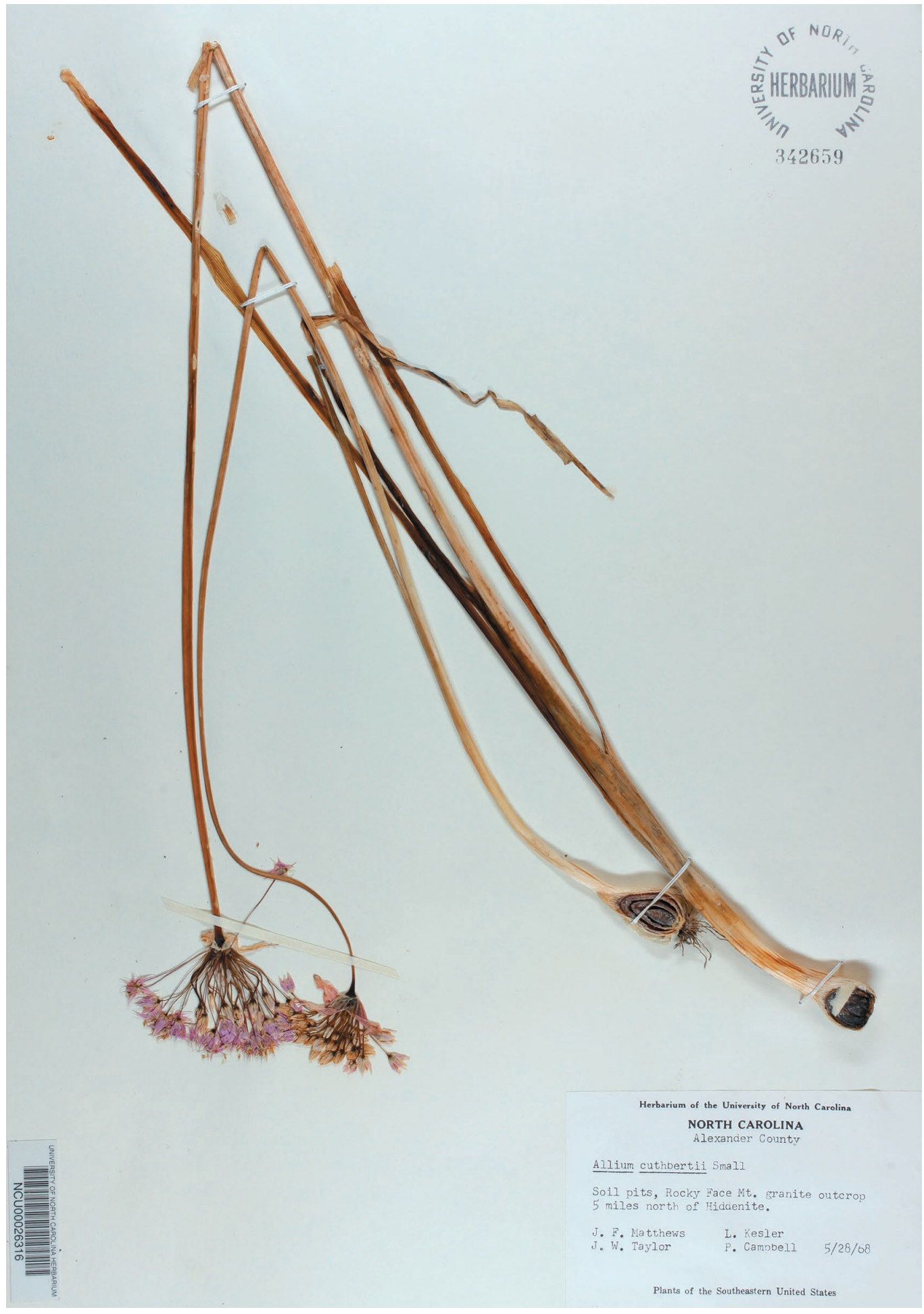

Fig. 4. Holotype of Allium keeverae D.B. Poind., Weakley, \& P.J. Williams, sp. nov. (Matthews, Kesler, Taylor, \& Campbell s.n., NCU; Alexander Co., NC) 
patterns of reticulation in concert with asexual modes of reproduction and clonal isolation. Consequently, phylogenetic inference in these apomictic lineages is obscured and an understanding of their sexual diploid progenitors is the first step to disentangling their evolutionary history (Noyes \& Groff 2011).

The sexual diploid populations are morphologically and genetically diverse, ranging from east Texas to South Carolina and notably occurring in areas of relictualism, including the Ozarks Plateau and Ouachita Mountains (Noyes \& Groff 2011), as well as the southern Appalachians of North Carolina and Virginia (unpublished data). In contrast, the range of polyploid apomicts is broader yet sympatric with diploids and extends much further north and west (Noyes \& Groff 2011).

Morphologically, diploids are often short-lived perennials from small rhizomes or caudices, produce conspicuous basal rosettes, have larger heads, and are found in "glade-like" situations uncharacteristic of the much more widespread apomictic polyploids that are biennial/annual and found in primarily ruderal situations. In 2001, Jim Allison described two new varieties of Erigeron strigosus, one (var. dolomiticola J. Allison) from Ketona dolomite outcrops in Bibb County, Alabama and another (var. calcicola J. Allison) growing over limestone in northern Alabama, northwest Georgia, and Middle Tennessee (Allison \& Stevens 2001). In describing the two new taxa, Allison pointed to their perennial habit, unique basal rosettes, and allopatric geographic distributions as defining characteristics that differentiated them from each other and the rest of E. strigosus. However, Allison chose a conservative approach and named these two entities as varieties of E. strigosus pending additional data. Noyes (2006) and Noyes and Groff (2011) explored the molecular phylogenetic relationships within sexual diploid populations of E. strigosus s.l. and found that both of Allison's infraspecific taxa were strongly differentiated genetically from each other and basal to a well-supported, derived clade containing the remaining sexual diploid E. strigosus populations. Importantly, data indicates that these edaphic specialists have not participated in reticulation, unlike the other nonspecialists that demonstrated reticulate hybridization (Noyes 2006). Pending further research, morphological, molecular, and ecological data support a necessary taxonomic shift to treat Allison's two varieties at the species level as genetically distinct progenitors that are part of the evolutionary history of E. strigosus, but sisters to the dominant, reticulate sexual diploid clade.

In elevating these two varieties to the rank of species, we are confronted with a need to clarify our position regarding Erigeron strigosus s.str. This name is associated with an apparent isotype at PH (S. Elliott 249, digital image PH00035744!), that is morphologically and geographically consistent with a polyploid apomict, and thus of unknown, but probably hybrid, evolutionary derivation. In light of the collective evidence, it seems most pragmatic to recognize all other sexual diploids and polyploids as pieces of a broader, unresolved E. strigosus until further study permits biologically significant taxonomic rearrangement. We intend to address this in a forthcoming publication.

Erigeron calcicola (J. Allison) D.B. Poind., B.R. Keener, \& Noyes, comb. \& stat. nov. Basionym: Erigeron strigosus Muhl. ex Willd. var. calcicolaJ. Allison, Castanea 66:173. 2001. TYPE: U.S.A. TeNNESSEE: Rutherford Co.: ca. $18.7 \mathrm{~km}$ E of Murfreesboro, ca. $3.7 \mathrm{~km} \mathrm{NNW}$ of Readyville, limestone glade W of Tassey Rd., ca. $0.2 \mathrm{rd}$. km N of crossing of Andrews Creek, 22 Jul 2000, James R. Allison 12431 (ноLотүPE, NY; IsOTYPES: DUKE, GA, GH, MO, NCU, TENN, UNA, US, VDB).

Erigeron dolomiticola (J. Allison) D.B. Poind., B.R. Keener, \& Noyes, comb. \& stat. nov. BAslonym: Erigeron strigosus Muhl. ex Willd. var. dolomiticola J. Allison, Castanea 66:169. 2001. Type: U.S.A. Alabama: Bibb Co.: ca. 12.4 km NNE of Centreville, "Westside East Glade," Ketona Dolomite outcrop ca. 0.4 km W of the mouth of Pratt Creek, 10 Jun 2000 , James R. Allison 12396 (holotype, NY; ISOTypes: AUA, BRIT, DUKE, FLAS, FSU, GA, GH, IBE, JSU, MICH, MO, NCU, TAMU, TENN, UARK, UNA, US, USCH, VDB).

LIATRIS: Chapman's L. tenuifolia var. quadriflora should be recognized, and at species rank

Liatris quadriflora (Chapm.) E.L. Bridges \& Orzell, comb. \& stat. nov. BAsIonym: Liatris tenuifolia Nutt. var. quadriflora Chapm., Fl. South. U.S., ed. 2:626. 1883. Type: "Banks of the Caloosa River, South Florida," Oct, no collector or date given, specimen not seen. Leстотуре, here designated: S. Florida, Herb. Chapman, presented to US in 1917 by Mrs. George W. Vanderbilt (US 968368 , Image No. 01659865).

For several years, we have been collecting morphometric, ecologic and phenologic data on Liatris series Pilifilis 
(Nesom 2005) in central Florida. This series has been treated as a single variable species (L. tenuifolia), one species with two varieties (L. tenuifolia vars. tenuifolia and quadriflora), and as two separate species (L. tenuifolia and L. laevigata Nutt.). Gaiser (1946) recognized two species, placing L. tenuifolia var. quadriflora in synonymy under L. laevigata, and this treatment was followed by Nesom (2006) in the Flora of North America. However, both Gaiser (1946) and Nesom (2006) allude to a third taxon in their discussion of variation within Liatris laevigata. Gaiser (1946, p. 291-292) discussed these "slender" forms of L. laevigata as representing possible intergradation with L. tenuifolia, and Nesom (2006) referred to them as "narrow-leaved forms" of L. laevigata, without suggesting they were intermediates between the two species. The majority of these narrow-leaved specimens are from central and southern peninsular Florida, only occasionally occurring northward to northeast Florida and the coastal Florida panhandle counties. The type of Chapman's Liatris tenuifolia var. quadriflora is from "Banks of the Caloosa River, South Florida," which we interpret as being from the Caloosahatchee River, between Lake Okeechobee and the Gulf Coast. We have not been able to locate a specimen matching this location at FLAS, FSU, NY, US, or USF. However, at NY and US there are several specimens with this variety name in Chapman's handwriting, all of which are the narrow-leaved slender form, so there is no doubt about the applicability of this name. In the apparent absence of any extant specimen with the specific location given by Chapman, we have chosen one of these as the lectotype. Curiously, there is no mention of Liatris laevigata, although published in 1841, in any of the three editions of Chapman's Flora, so we do not know if he ever saw specimens referable to this species.

During our field surveys of populations from six peninsular Florida counties within the range of all three species, we found differences among them in morphology, habitat and phenology. Where two of the three species co-occurred, there were rarely any intermediates, even when growing side by side. Liatris tenuifolia and $L$. laevigata are both xeric psammophytes, restricted to upland sandy entisols and entic spodosols. In central Florida, Liatris tenuifolia is primarily restricted to well-drained sandhills, typically on yellow sands, where it is associated with numerous central Florida sandhill specialists. Liatris laevigata is primarily found in excessively drained white sand scrub, and also occurs on somewhat poorly drained gray sands of scrubby pinelands. In both habitats it is associated with sclerophyllous oaks (Quercus myrtifolia, Q. chapmanii, Q. geminata, Q. inopina). In contrast, Liatris quadriflora occurs principally in pineland savannas and hyperseasonal geoxyle grasslands on mesic to wet poorly drained spodosols and alfisols. In these habitats, it is often sympatric with Litrisa carnosa, Trilisa subtropicana, and Liatris gracilis.

In central Florida, the earliest in the group to flower is Liatris laevigata, which can be at anthesis in July, and in peak flower in August to early September, when wet season rainfall increases soil moisture within its xeric habitat. Flowering times can be delayed if the habitat is burned late April through early June. Liatris tenuifolia is in peak flower from September to early October, during the late wet season. When sympatric, there is a difference in peak flowering between these two species of 15 to 30 days. In contrast, flowering of Liatris quadriflora does not begin until mid-October, with peak flowering extending into mid-November, when the soil becomes less saturated at the start of the dry season. Where L. laevigata occurs in better drained habitat near populations of L. quadriflora, it has disseminating fruit by the time L. quadriflora starts flowering.

Based on 15 character traits recorded at 20+ populations each of L. laevigata and L. quadriflora, Liatris laevigata is a shorter (total culm height, including the inflorescence, mostly $50-80 \mathrm{~cm}$ ), stouter (culm width 4-6 mm) plant, with the inflorescence occupying about half of the total culm height. In Liatris quadriflora, total culm height averages $75-100 \mathrm{~cm}$, and culm width 2-3 mm, with the inflorescence occupying only about $25 \%$ of the total culm height. The basal leaves of L. laevigata average 15-20 cm long and 5-7 mm wide, and there are often 20-40 or more basal leaves per culm. In contrast, the basal leaves of L. quadriflora average 25$30 \mathrm{~cm}$ long and 2-3 mm wide, with about 10-15 basal leaves per culm.

The following key can be used to distinguish Liatris quadriflora from L. laevigata:

1. Leaves in a well-defined, densely leafy basal rosette, (4-)5-7(-10) $\mathrm{mm}$ wide and $15-20 \mathrm{~cm}$ long, mostly lax and spreading, not ascending; culms (40-)50-80(-120) cm tall, 4-6 mm wide, the inflorescence averaging half the culm height; flowering mostly from July to September, during the wet season in peninsular Florida. 
1. Leaves in a diffuse, few-leaved basal rosette, $2-3 \mathrm{~mm}$ wide and $20-30 \mathrm{~cm}$ long, mostly somewhat ascending; culms $(60-) 75-100(-150) \mathrm{cm}$ tall, $2-3 \mathrm{~mm}$ wide, the inflorescence averaging $25 \%$ of the culm height; flowering mostly from October to November, during the dry season in peninsular Florida

L. quadriflora

TRILISA: The "subtropicana" entity warrants species rank, now in Trilisa

Trilisa subtropicana (DeLaney, N. Bissett, \& Weidenh.) E.L. Bridges \& Orzell, comb. \& stat. nov. Basionym: Carphephorus subtropicanus DeLaney et al., Bot. Explor. (Florida) 1:2. 1999. Carphephorus odoratissimus (J.F. Gmel.) H. Hebert var. subtropicanus (DeLaney, N. Bissett, \& Weidenh.) Wunderlin \& B.F. Hansen, Novon 11:366. 2001. Type: U.S.A. Florida. Polk Co.: $4.36 \mathrm{mi}$ E of US 27 on Avon Park Cut-Off Road, T32S, R27E, Sec. 21, SE $1 / 4,27^{\circ} 40^{\prime} 37^{\prime \prime} \mathrm{N}, 81^{\circ} 37^{\prime} 05^{\prime \prime} \mathrm{W}, 9$ Oct 1999, Bissett 1001 (HOLOTYPE: USF; ISOTYPES: FLAS, FSU, FTG, GA, NY, USF).

The merger of Trilisa (and the Florida endemic genus Litrisa) into Carphephorus has recently been questioned (Schmidt \& Schilling 2000; Schilling 2011). As broadly circumscribed, the genus Carphephorus does not form a monophyletic clade, with Trilisa forming a clade clearly distinct from all other species of Carphephorus. Although generic limits in the subtribe Liatrinae remain imperfectly resolved, it seems from molecular studies that in order to have monophyletic genera, either almost every species in the subtribe would need to be subsumed into a broadly defined and diverse genus Liatris, or, that each clade within Carphephorus be recognized at the generic level. Although this may in the future necessitate the designation of additional segregate genera, there is no doubt that Trilisa will be one of these.

Trilisa subtropicana differs from T. odoratissima (J.F. Gmel.) Cassini in plant odor, leaf characters, and inflorescence size and shape. Perhaps the most striking difference between these two species is the lack of a strong coumarin odor in T. subtropicana. Small (1933) first noted that Trilisa odoratissima might represent two species, one with a strong coumarin odor, broad, clasping, coarsely toothed upper leaf blades and slightly viscid involucres (T. odoratissima, sensu stricto) and one with only a faint odor, narrow entire upper leaf blades and very viscid involucres, the entity described in DeLaney et al. (1999) as Carphephorus subtropicanus.

In addition to the conspicuous lack of coumarin odor, several morphologic characters differentiate Trilisa subtropicana and T. odoratissima. Most plants of T. subtropicana have only one or two flowering stems per clump (mean=1.6, std=0.8), whereas in central Florida $T$. odoratissima averages over twice as many inflorescences per clump (mean=4.1, std=1.9). Several characters of the basal and stem leaves have different mean character states. Although there is variation in leaf size and shape within populations in both species, and between lower and upper leaves on a single plant, comparison of leaves in the same relative position on plants of the two species reveals consistent differences. The basal leaves of $T$. subtropicana are both shorter (mean=11 $\mathrm{cm}$ ) and narrower (mean=3.0 cm) than those of $T$. odoratissima (mean length=19.8 cm; mean width=5.6 cm). The stem leaves of T. odoratissima are broadly elliptic, and although the base of the leaf clasps the stem, the apex of the leaf is often divergent or flared away from the stem. The margins of the stem leaves in T. odoratissima are often coarsely shallowly toothed. In contrast, the stem leaves of $T$. subtropicana are narrowly elliptic, clasp the stem for their entire length, and have entire margins.

The inflorescence of Trilisa subtropicana is much broader than that of T. odoratissima, and on well-developed mature plants is almost always as wide or wider than tall. This difference is attributable to the angle of branching of the primary inflorescence branches from the main axis. The inflorescence branches of $T$. subtropicana diverge from the main axis at an angle of from $30^{\circ}$ to $45^{\circ}$, and are often arcuate, resulting in a rather open and diffuse inflorescence. In contrast, the main inflorescence branches of $T$. odoratissima diverge from the main axis at an angle of $10^{\circ}$ to $20^{\circ}$, resulting in a narrower, taller, inflorescence which is typically taller than wide. This open, diffuse inflorescence, more so than in any other species of Trilisa or Carphephorus, is a reliable character for field recognition of T. subtropicana.

There are few differences in inflorescence and floral characters between these two species. There is often much variation within a single plant in number of florets per head, size of heads, and size of floral parts. There is a tendency for T. subtropicana to have more florets per head (10-13) than is typical for T. odoratissima (7-10). However, this could be attributable to the fact that most T. subtropicana inflorescences consist of only 50 to 75 heads, in contrast to the hundreds of heads present in some inflorescences of T. odoratissima, therefore a larger 
proportion of heads fully develop all of their potential florets. This difference in resource allocation may also explain the slightly longer $(3.0 \mathrm{~mm})$ achenes of $T$. subtropicana in comparison to the shorter $(2.0-2.5 \mathrm{~mm})$ achenes of T. odoratissima.

The following key can be used to distinguish Trilisa subtropicana from Trilisa odoratissima:

1. Plants with a strong odor of coumarin or vanilla; basal leaves usually more than $15 \mathrm{~cm}$ long and $5 \mathrm{~cm}$ wide; midstem leaves broadly elliptic, the apex flared away from the stem, the margins often shallowly toothed; inflorescence taller than wide (height:width ratio of 1.5:1 to 3:1), the primary inflorescence branches diverging from the main axis at a $10^{\circ}$ to $20^{\circ}$ angle; heads mostly with 7-10 flowers; achene $2.0-2.5 \mathrm{~mm}$ long

T. odoratissima

1. Plants with very slight or no odor of coumarin or vanilla; basal leaves less than $15 \mathrm{~cm}$ long and $4 \mathrm{~cm}$ wide; midstem leaves narrowly elliptic, tightly clasping the stem, the margins entire; inflorescence wider than tall (height:width ratio of $0.5: 1$ to $1: 1$ ), the primary inflorescence branches diverging from the main axis at a $30^{\circ}$ to $45^{\circ}$ angle; heads mostly with 10-13 flowers; achene $3.0 \mathrm{~mm}$ long

T. subtropicana

\section{CALYCANTHACEAE}

CALYCANTHUS: No varieties of Calycanthus floridus

For most of the last half-century, two varieties have usually been recognized in Calycanthus floridus L., var. floridus with pubescent twigs, petioles, and leaf undersurfaces, and var. glaucus (Willd.) Torr. \& A. Gray [or var. laevigatus (Willd.) Torr. \& A. Gray] with glabrous (or sparsely pubescent) twigs, petioles, and leaf undersurfaces. Nicely (1965) recognized these two varieties and presented a map showing some geographic separation of them, though collections subsequent to his study have resulted in an almost complete geographic overlap of the alleged entities. The simplicity of the pubescence character and its relative ease of application to herbarium specimens and plants in the field has led to the wide acceptance of the two varieties in continental, regional, and state floras in the United States, including Gleason and Cronquist (1991), Fernald (1950), Godfrey and Wooten (1981), Johnson in FNA (1997), Wunderlin and Hansen (2011, 2015), Rhoads and Block (2007), Radford et al. (1968), Tennessee Flora Committee (2015), or even at species rank by Gleason (1952) and Small (1933). Nicely (1965) nicely and appropriately reduced the usual rank of recognition from species to variety, but it now seems that he did not go far enough. Based on field experience and herbarium specimens from across the eastern North American distribution of Calycanthus, these two alleged entities have broadly overlapping distributions and no other morphological, ecological, or phenological characters that correlate with the variable pubescence character. There is no apparent basis to regard the variable pubescence character as anything other than trivial and taxonomically uninformative variation. We therefore recommend treating Calycanthus floridus as a species with no infraspecific entities.

\section{ERICACEAE}

GAYLUSSACIA: A new character to distinguish G. nana from G. frondosa and G. tomentosa

The Gaylussacia frondosa complex has been taxonomically controversial, with 1-3 taxa recognized, at species or variety rank, and in Gaylussacia or the segregate genus Decachaena; Small's segregates in SEUS vaccinioids may yet prove prescient but clarity about generic treatment remains elusive.

Most recently, three species have usually been recognized and placed in the genus Gaylussacia, as by Duncan and Brittain (1966), Luteyn et al. (1996), Sorrie et al. (2009), Weakley (2015), though skepticism about rank or even taxonomic recognition has remained (Wunderlin \& Hansen 2011). Some of this skepticism has been generated by subtleties and variability in the characters used to recognize the three taxa, including height of plants, glaucousness and pubescence of leaves, size of leaves, and pubescence of twigs of the season.

In his classic publication on woody plants, Godfrey (1988) treats Gaylussacia tomentosa (A. Gray) Small and G. nana (A. Gray) Small as varieties under G. frondosa (L.) Torr. \& A. Gray. While not providing a key, Godfrey's descriptions include characters that he used to separate the taxa: plants taller (to $1 \mathrm{~m}$ ) and loosely branched, twigs not glaucous, larger leaves $3-6 \mathrm{~cm}$ long and not glaucous beneath in tomentosa; vs. plants smaller [2-6(-10) dm] and with short branches and a columnar aspect, twigs glaucous, and larger leaves 2-4 $\mathrm{cm}$ long and glaucous beneath in nana.

Godfrey suggests that "perhaps the two taxa ... are best considered to be specifically distinct ..." and cites 
Duncan and Brittain (1966) and Judd ("pers. comm."). These authors, plus Luteyn et al. (1996), use the same characters in their keys as Godfrey.

While the morphological characters noted above appear to be relatively strong (with practice), there are examples in the field and herbarium where certain plants are difficult to place. These include specimens with intermediate expressions of pubescence on twigs and leaves, and individuals of $G$. nana which show little glaucescence on leaf undersides. Confusion can also arise between G. nana and G. frondosa sensu stricto in southeastern North Carolina and northeastern South Carolina, since both species there exhibit little pubescence.

Specimens of the Gaylussacia frondosa complex at NCU were examined for additional characters than those given by Godfrey (1988): 166 specimens of G frondosa s. str. (115 NC, 51 SC); 70 specimens of G. tomentosa (10 SC, 43 FL, 16 GA, 1 LA); and 49 specimens of G. nana (from NC to FL and AL). It soon became apparent that color of the leaf glands was informative.

Sessile, glandular, resin dots occur on the undersurface of all leaves of the G. frondosa group. These glands are golden yellow in G. frondosa and G. tomentosa (Fig. 5), whereas they are distinctly red in G. nana (Fig. 6). Therefore, by itself this character will reliably distinguish G. nana in areas of overlap with the other two species. We found no specimens in which gland color was intermediate in tint; all G. nana showed a red tint that was absent in $G$. frondosa and $G$. tomentosa. Note also the apparent size difference in glands: those of $G$. nana appear to be consistently wider than those of $G$. frondosa and $G$. tomentosa. While I did not measure gland width, it may be another useful distinguishing character.

As a caveat, it should be noted that some older specimens of G. nana at NCU, notably collections by Ashe, Totten, and others prior to 1930, showed either 1) golden yellow glands or 2) no obvious glands at all. However, these conditions appear to be atypical, since specimens of G. nana collected by Ashe in 1929 from Wakulla County, Florida; by Ashe in 1923 from Houston County, Alabama; and by Earle \& Baker in 1897 from Lee County, Alabama; possessed typically red glands. Thus, age by itself does not cause glands of G. nana to shift color; more likely this change in gland appearance is an artifact of unsatisfactory drying of specimens.

\section{FABACEAE}

DALEA: Dalea floridana, a narrowly endemic species of southern Florida

The geographically and ecologically distinct prairie clover, Dalea carthagenensis (Jacq.) J.F. Macbr. var. floridana (Rydb.) Barneby, should again be elevated to specific rank, given modern concepts of species, as D. floridana (Rydb.) Diggs \& Weakley. In his 1977 revision, Daleae Imagines, Barneby includes this taxon (previously treated at species rank, as Parosela floridana Rydb.) as a varietal component of an enormous species complex (with nine named varieties) native to South America, Central America, Mexico, and the Caribbean, with the D. carthagenensis var. floridana entity the only member of this complex native to eastern North America (Barneby 1977).

Barneby (1977) describes D. carthagenensis as "a polymorphic species of immense, discontinuous dispersal" and admits that "this treatment is in some respects immoderately simplified." He further states that "it is proposed here to divide the material [taxa of series Thyrsiflora] into two primary specific groupings, $D$. carthagenensis and D. scandens."

These statements suggest that Barneby has created taxonomies of convenience by grouping together "entities" based on general morphological similarity, and the means to do this in his monumental monographs was to take taxa (mostly) formerly treated as species, reduce them to varietal rank, and then group the varieties into "species." This enabled Barneby in Daleae Imagines and others of his legume tomes to create order out of chaos as a provisional treatment of large and difficult groups, many of them with extensive and undercollected tropical distributions, but it makes a different use of the species and variety rank than would be followed in applying modern species concepts. The implication that the nine varieties of $D$. carthagenensis are more closely related to one another than to other entities in the genus is merely conjectural, and that they are held together by gene flow seems unlikely (and see Mimosa, below).

The assertion that the "var. floridana" taxon is obviously closely related to the taxa of D. carthagenensis 


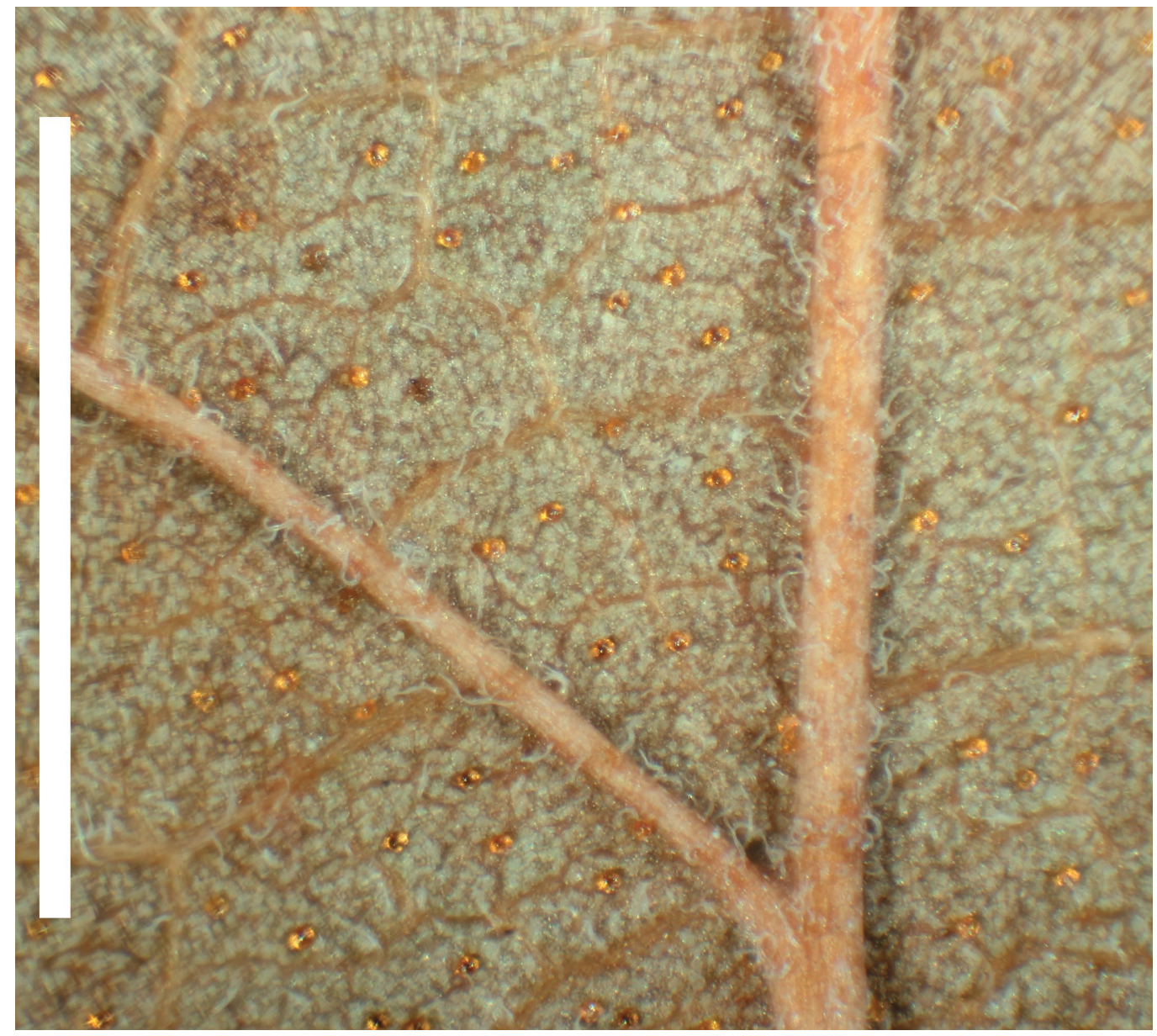

FIG. 5. Gaylussacia frondosa, abaxial leaf surface, Ahles 47938 (NCU). Scale bar $=3 \mathrm{~mm}$. Image by Derick B. Poindexter.

found in the Caribbean is contradicted by several morphological differences - notably smaller and more numerous leaflets of the primary cauline leaves (15-25 vs. 9-17 leaflets), significant seasonal variation in leaf morphology (a feature not noted in the Caribbean taxa), and clear differences in flowering period.

Second, the habitat differences and geographical restriction of this plant from the other Dalea carthagenensis taxa are underemphasized. Other taxa in this complex are described as generalists in microhabitat. Dalea carthagenensis var. carthagenensis occurs at variable elevations up to 1000 meters in "thickets near the coast and on brushy hillsides" into the interior of Colombia, Venezuela, and the Lesser Antilles. Dalea carthagenensis var. barbata is widely dispersed throughout Central and South America from Chiapas, Mexico to Colombia, where it inhabits savannas and thickets from sea level to 2000 meters in elevation. By contrast, the "var. floridana" entity is a strict inhabitant of pine rocklands and a few other calcareous rock outcrop habitats in eastern Florida, being now restricted to a handful of remnant sites in Miami-Dade County. This plant is narrowly endemic to peninsular Florida, and shows none of the range, elevation, or habitat variability of the other putative members of the complex.

We reason that $D$. floridana warrants species rank, as geographically isolated in south Florida, in specialized habitats, and morphologically distinct from its presumed closest relatives in several features. In order to 


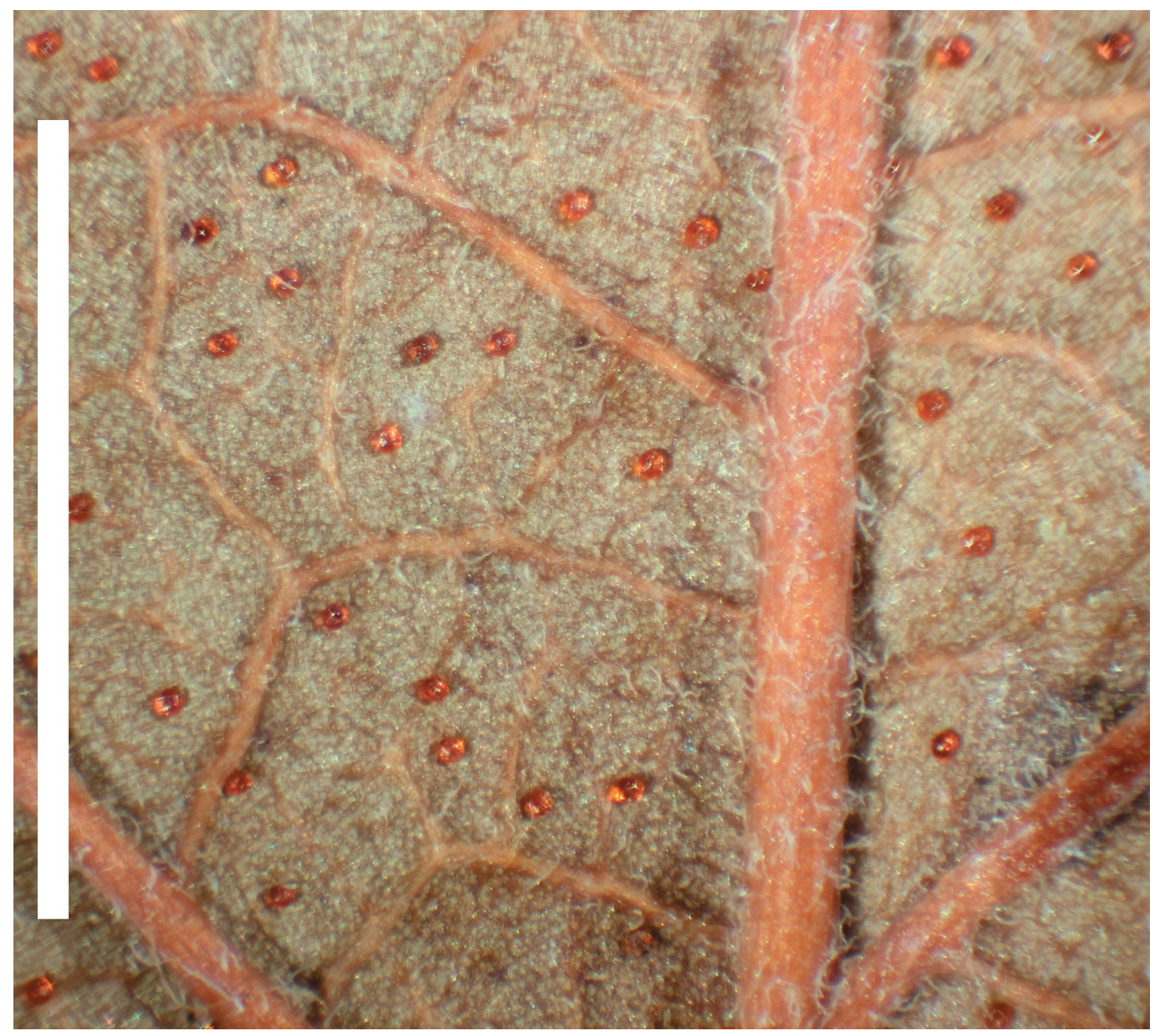

FIG. 6. Gaylussacia nana, abaxial leaf surface, Bozeman 10107 (NCU). Scale bar $=3 \mathrm{~mm}$. Image by Derick B. Poindexter.

recognize taxon "floridana" at species rank, and for now in Dalea (pending continuing molecular analysis), a new combination is proposed.

Dalea floridana (Rydb.) Diggs \& Weakley, comb. \& stat. nov. Basıonym: Parosela floridana Rydb., N. Amer. Fl. 24(2):114. 1919. TyPE: FLORIDA: Miami, Nov 1878, A.P. Gerber (HOLоTYPE: NY). Dalea carthagenensis var. floridana (Rydb.) Barneby, Mem. N.Y. Bot. Gard. 27. 1977.

MIMOSA: Mimosa quadrivalvis var. floridana returned to species rank as M. floridana

Barneby (1991) included Schrankia in Mimosa as sect. Batocaulon, ser. Quadrivalves, a conclusion foreshadowed by many authors before him, and largely if not completely followed by all authors since. Pertinent to the SEUS flora, he also treated the series as a single species ranging from South Dakota to southcentral South America, with 16 "either vicariant and intergrading or some sympatric and better differentiated varieties." This reduction of 15 species to varietal rank has not been well-received, with Turner (1994a, 1994b) and Grether (2000) studying the group and re-elevating 11 of the 14 non-autonymic taxa to specific rank in Mimosa. Flores-Cruz et al. (2004) studied leaflet anatomy for its taxonomic utility in the group, and concluded that "most of the taxa studied [including some that had been re-elevated and others that have not] are morphologically and geo- 
graphically well-delimited. The results from leaflet anatomy support this conclusion, and furthermore support the treatments by Turner (1994a, b, c) and Grether (2000)."

Of the 11 extratropical taxa (of the United States and northern Mexico) treated at varietal rank by Barneby (1991), all but M. quadrivalvis var. floridana have since been reinterpreted to warrant specific rank. Flores-Cruz et al. (2004) specifically noted that "variety floridana is the only infraspecific taxon of M. quadrivalvis placed in Group I" based on venation characteristics, and that "the anatomical results, along with morphological characters, support the placement of this taxon in Group I, which implies that it should be recognized as a species distinct from M. quadrivalvis." If, as seems likely, the multiple leaflet anatomy characters used by Flores-Cruz et al. (2004) to group taxa into groups are conservative characters implying relationship, the narrowly endemic M. quadrivalvis var. floridana is clearly quite distinct (at species rank) from Mimosa microphylla Dryand. [= M. quadrivalvis var. angustata], with which it is sympatric (within the latter's much broader distribution) (see comparison of characters in the key below). Mimosa quadrivalvis var. floridana's relationship appears to be with other taxa of Group I, which are distributed west of the Mississippi River in the southcentral United States and northern Mexico. The biogeography of M. quadrivalvis var. floridana (Florida peninsula north to southeastern Georgia) and habitat in Florida scrub and longleaf pine sandhill habitats (habitats with a strong relict and endemic flora and fauna) corroborate the already strong case for species status for this entity.

Mimosa floridana (Chapm.) Weakley \& Flores-Cruz, comb. \& stat. nov. BAsIonym: Schrankia floridana Chapm., Fl. South. U.S., ed. 2 [Appended] 683. 1892. TYPE: FLORIDA: Manatee, s.d., Simpson s.n. (ноLоTYPE: NY-fragment).

The following key separates the two known species of series Quadrivalves occurring in the SEUS east of the Mississippi River. It should be noted that variation within M. microphylla (note, for instance, the three fruit types described by Barneby 1991) suggests the possible presence of several taxa additional to those here recognized. The key below emphasizes the most widely seen fruit type "c" of Barneby (1991).

1. Leaflets 17-20 pairs per pinna; leaflet apex obtuse; heads globose; peduncle 1.4-2.5 cm long; flowers sessile; legumes 9.3-13.5 cm long; prickles of the legume simple, strongly curved

M. floridana

1. Leaflets 12-16 pairs per pinna; leaflet apex mucronate; heads subglobose; peduncle $4.5-6.5 \mathrm{~cm}$ long; flowers pedicellate; legumes $4.6-5.5 \mathrm{~cm}$ long; prickles of the legume branching, slightly curved

M. microphylla

\section{HYDROPHYLLACEAE (OR BORAGINACEAE S.L.)}

HYDROPHYLLUM: Retention of Hydrophyllum virginianum var. atranthum as distinct from $H$. virginianum var. virginianum

The taxonomic status of dark-purple-flowered populations of Hydrophyllum virginianum L. in the Southern Appalachians has long been debated. In 1941, EdwardJ. Alexander described these populations as Hydrophyllum atranthum Alexander based on this striking color difference in conjunction with deep corolla lobing, long and slender filaments, brown appendages, lack of pubescence along stem, and increased segmentation of the leaves. After its description, a trend in taxonomic demotion ensued. Lincoln Constance (1942) assigned varietal status to these populations, as var. atranthum (Alexander) Constance, and later Robert Beckmann (1979) concluded that the Southern Appalachian populations warranted no distinction from the typic white- or lavender-flowered forms of the species. No morphometric or molecular work has been conducted on these populations since $H$. atranthum was first recognized by Alexander almost 100 years ago. As with many taxonomic concepts, there is a paucity of information regarding the logic behind choices in rank and outright dismissal.

To assess the potential validity of Alexander's taxon, we examined all collections at NCU. These specimens covered the full geographic distribution of the species across central and eastern North America. Morphological data was recorded for corolla lobing and coloring, stem and leaf pubescence, stamen length and width, and appendage coloration. In addition, we utilized the extensive georeferenced photo library available through iNaturalist to examine live coloration patterns for more accurate data than conventionally faded herbarium specimens. For most specimens, the corolla, filament, stamen, and appendages can be viewed in enough detail to clearly observe pigments. Measurements from these digital archives were not practical due to the lack of scale. 
With the exception of pigmentation (see Table 1, below), all other morphological characters are either overlapping or uninformative. There is no evidence of the claims that $H$. virginianum var. atranthum has shorter or more slender stamens or increased segmentation of the leaves. Lobing of the corolla is consistently longer than the corolla tube for $H$. virginianum var. atranthum, but lobing could be longer, shorter, or equal to tube length throughout the range of $H$. virginianum var. virginianum. The diagnostic brown pigmentation of $H$. virginianum var. atranthum noted by previous authors reflects medium to dark purple coloring which had senesced to brown before or after pressing.

Beckmann (1979) argued that the dark-purple "color morphs" occur in several regions outside of the Southern Appalachians and were thus unworthy of distinction. Although an individual with medium-purple corollas does rarely occur within a population of typical $H$. virginianum, this coloration never approaches the darkness of the purple that is consistent at a population level in the Southern Appalachians. Canadian specimens near Toronto display various darkening shades of purple, but there is no consistency among nearby populations, no dark purple coloring on stamens, and often white pigmentation present at petal edges (iNaturalist). NCU herbarium specimens collected near Cuyahoga Valley National Park of northern Ohio (A. Cusick 327 and 9771) have deep purple pigmentation but are described as uncommon in a population of light purple morphs. iNaturalist photos from this area show medium-purple pigmentation of the corollas and light-purple pigmentation of corolla bases, appendages, stamens and styles.

Differences in pigmentation of $H$. virginianum are primarily due to levels of production of delphinidin, a common anthocyanin in plants (Beckmann 1979). Delphinium tricorne Michx. is found in the same rich cove habitat and general distribution as H. virginianum and often displays a wide range of delphinidin-influenced floral pigments from white to blue to purple to pink within a single population, even in the Southern Appalachians (personal observation). The consistency of deep-purple pigmentation of $H$. virginianum var. atranthum produced by similar chemical mechanisms and environmental conditions as the inconsistently pigmented D. tricorne is significant. Further, a study of flower color polymorphism in populations of Hydrophyllum appendiculatum Michx. found corolla pigmentation to be linked to other reproductive genes such as inflorescence production (Wolfe 1993). This bolsters the genetic significance reflected in phenotypic variation of corolla color within the genus. If the H. virginianum (eastern) and H. tenuipes (western) complex is the basalmost representation of the genus as suggested by Beckmann (1979), the highest genetic diversity likely exists in the long-unglaciated biodiversity repository of the Southern Appalachians. These studies and details support a distinct evolutionary lineage that requires further study.

After reevaluating the previously mentioned characters for $H$. virginianum across its range and finding many informative characters to be upheld, we conclude that varietal status (at least) of $H$. virginianum var. atranthum is warranted.

The following key, adapted from Weakley $(2015,2017)$ can be used to separate the two taxa.

1. Corolla, stamens, and appendages deep purple and fading to medium brown in herbarium specimens; lower stem glabrous to slightly (rarely moderately) pubescent with retrorse hairs; [of low to high elevations in the Mountains]

Hydrophyllum virginianum var. atranthum

1. Corolla, stamens, and appendages white to lavender or pale purple and fading to yellow or light brown in herbarium specimens; lower stem slightly to densely pubescent with retrorse to spreading hairs; [of low and mid-elevations of the Piedmont, Mountains, and Coastal Plain] Hydrophyllum virginianum var. virginianum

In contrast to APG IV (Angiosperm Phylogeny Group 2016), we here recognize smaller families in the Boraginales (including the Hydrophyllaceae) following Boraginales Working Group (2016).

\section{HYMENOPHYLLACEAE}

DIDYMOGLOSSUM: The peninsular Florida endemic filmy-fern transferred to Didymoglossum Following the publication of Ebihara et al. (2006), Didymoglossum Desv. is now routinely accepted as a genus separate from Trichomanes L. In their overview of the generic and subgeneric taxonomy of family Hymenophyllaceae, Ebihara et al. (2006) made combinations needed to bring all accepted taxa at species rank into the accepted generic level taxonomy employed, but they did not make any new combinations at 
TABLE 1. Informative characters in Hydrophyllum virginianum s.I.

H. virginianum var. virginianum

Pale yellow, lavender, light to (rarely) medium purple, often light brown mottling at the base

Corolla pigment of live specimens

Stamen and appendage pigment of herbarium specimens Stamen and appendage pigment of live specimens

Lower stem pubescence

Geographical distribution
Pale yellow, lavender, light to (rarely) medium purple Pale yellow, lavender, light to (rarely) medium purple, and light brown White, pale yellow, lavender, and light to (rarely) medium purple Slightly to densely pubescent with retrorse and spreading hairs Low and mid-elevations, widespread in the Central and Eastern US
H. virginianum var. atranthum

Medium to very dark purple, often medium to dark brown mottling at the base

Medium to very dark purple

Medium to very dark purple and medium to dark brown

Medium to very dark purple

Glabrous to slightly (rarely moderately) pubescent with retrorse hairs Low to high elevations in the Southern Blue Ridge Mountains

infraspecific ranks, presumably because that might imply an independent assessment of the "goodness" of those taxa, which was not in the scope of their work focused at generic and subgeneric ranks.

Wessels Boer's (1962) monograph of New World Trichomanes sections Didymoglossum and Microglossum (with collectively the same circumscription as Ebihara et al.'s [2006] concept of genus Didymoglossum) remains the primary source of our species and subspecies taxonomy of this genus in the New World. He treated Trichomanes punctatum as having "four more or less clear-cut subspecies." Two of the three non-typic subspecies have recently been transferred to Didymoglossum (Boudrie \& Cremers 2016), leaving only Trichomanes punctatum ssp. floridanum without a name in Didymoglossum.

As reviewed in the federal listing documents for Trichomanes punctatum subsp. floridanum under the Endangered Species Act (USFWS 2014), virtually all authorities in Florida treat the subspecies as a valid entity distinct from West Indian taxa, and recent genetic analyses indicate that the two widely separated metapopulations in Florida (Miami-Dade County, Sumter County) are the same entity.

Trichomanes punctatum subsp. floridanum was listed as Endangered in the United States in 2015, and is of high conservation concern. While its taxonomic status has not been carefully revisited since Wessels Boer (1962), the review done by USFWS accepted it as a valid taxon and there are no evidence-based opinions contrary to its acceptance as a "good" taxon.

Infraspecific recognition seems appropriate, in the absence of careful studies that might better elucidate the genetic differentiation of the taxa within D. punctatum, their age, relationships, and evolutionary history. While we overall prefer the use of variety as the primary infraspecific rank (see introduction), we make an exception in this case and use subspecific rank for parallelism with Wessels Boer's (1962) treatment in Trichomanes, and because the other infraspecific taxa have been recently transferred at subspecific rank by Boudrie and Cremers (2016).

Didymoglossum punctatum (Poir.) Desv. subsp. floridanum (Wess.Boer) Weakley \& Gann, comb. nov. BAsIonym: Trichomanes punctatum Poir. subsp. floridanum Wess.Boer, Acta Bot. Neerl. 11:299, f. 18(a-b). 1962. Type: U.S.A. FLoridA. Miami-Dade Co.: Large hammock E of Brown's, s.d., Eaton 561 (ноцотүPE: GH).

\section{LAMIACEAE}

MONARDA: Monarda fistulosa var. brevis elevated to species rank

The Monarda fistulosa L. complex has had several varieties recognized based on their respective distributions and morphological characters (Fosberg \& Artz 1953, Scora 1967). Most distinctive of these varieties is the dwarf, early flowering M. fistulosa var. brevis Fosberg \& Artz from limestone glades in Virginia and West Virginia. Fosberg and Artz (1953) distinguished it from the nominal variety based on its short stature, firm dark green leaves with minimal serration, and the pustulate glandular calyx lobes. This latter character is 
shared with M. austroappalachiana Floden, M. luteola Singhurst \& Holmes, M. stipitatoglandulosa Waterf. and several novel species in preparation (Campbell and Floden ined., Floden 2015). Fosberg and Artz (1953) and Scora (1967) reported that in a common garden that M. fistulosa v. brevis retained its dwarf habit, which has been corroborated by AJF, with most North American Monarda species cultivated in a common garden. Not only are their habits maintained in cultivation, but their range of flowering times differ with very little overlap (Floden 2015, Weakley et al. 2012). Moreover, Kimball et al. (2001) provided genetic evidence of its distinctiveness and limited gene flow between $M$. fistulosa and the variety with manifestly different allele frequencies observed between the two species. Given the long recognized morphological differences that distinguish it and its genetic differences we propose to recognize it at specific level in advance of the upcoming Lamiaceae treatment for the Flora of North America and to emphasize the conservation priorities for this rare species.

Monarda brevis (Fosberg \& Artz) Floden, comb. nov. BAsIonym: Monarda fistulosa L. var. brevis Fosberg \& Artz, Castanea 18:130. TYPE: U.S.A. West Virginia. Pendleton Co.: talus at base of limestone cliff on mountainside above right bank of South Branch of the Potomac River near southern entrance to Smoke Hole, 27 Jun 1953, Lena Artz 1232 (ноLотүPE: US; ISOTYPE: WVU).

\section{MALVACEAE}

KOSTELETZKYA: Taxa in Kosteletzkya pentacarpos (L.) Ledeb.

Morphometric examination of Kosteletzkya pentacarpos (L.) Ledeb. across its range in North America resulted in a new combination, K. pentacarpos var. smilacifolia (Chapm.) S.N. Alexander, and the synonymization of all other named varieties with K. pentacarpos var. pentacarpos (Alexander et al. 2012). Statistical analysis of 42 vegetative and reproductive characters drawn from 224 herbarium specimens revealed that only individuals assigned to K. pentacarpos var. smilacifolia were significantly distinctive to warrant recognition as a named variety. This variety is restricted to peninsular Florida and is characterized by its much smaller size relative to the eponymous variety, unbranched inflorescence, and very narrow - in some cases almost linear- hastate leaves (Fig. 7). Thorough investigation of regional herbaria show this species has been irregularly collected since its description in 1860 and remains rare in herbaria. The most recent collection that we are aware of was made in 2006 at Oscar Scherer State Park in southwestern Florida (Sarasota County). Given that the apparent habitat of K. pentacarpos var. smilacifolia is similar to that found elsewhere in the species' range along the Gulf and Atlantic coastlines, we suspect that the morphological differences observed in this variety have a strong genetic basis. We hypothesize that K. pentacarpos var. smilacifolia may be a genetically cohesive lineage that has arisen as a consequence of similar historical biogeographic processes that have driven the evolution of other taxa endemic to peninsular Florida (Estill \& Cruzan 2001; Fetter 2014). A molecular phylogeographic investigation of K. pentacarpos across this species' range in North America, the Caribbean, and the Mediterranean is needed to test this hypothesis and to understand the origin of the European populations, which may have been introduced from the Americas prior to Linnaeus' first description of this species in 1753.

SIDA: A new genus for the phylogenetically, biogeographically, and morphologically isolated Sida hermaphrodita

The correct generic placement of the plant generally known since 1894 as Sida hermaphrodita (L.) Rusby has long been problematic. Named in Napaea by Linnaeus (1753), N. hermaphrodita L. was first transferred to Sida by Cavanilles (1788), as Sida napaea Cav., an illegitimate name, and then by Rusby (Committee of the Botanical Club 1894) as Sida hermaphrodita (L.) Rusby. Asa Gray (1849) placed the species in section "Pseudo-Napea," consisting of two species, S. hermaphrodita and S. hulseana, since removed to Abutilon. Clement (1957) treated the section [spelled as "Pseudonapaea"] as monotypic and stated that it "has no close affinities with any other in the genus [Sida], nor with Napaea save in habit." In his treatment of Sida of North America (including Mexico) Fryxell (1985) agreed, quoting Clement and adding "it [section Pseudo-napaeae] is also geographically and ecologically distinct from the remainder of Sida, being a temperate-zone plant whereas Sida is typically tropical and subtropical. One might plausibly argue that the section be elevated to generic rank." In 1997, Fryxell went further, stating that "Sida hermaphrodita probably deserves segregation into a distinct genus."

Recent molecular studies using nrDNA ITS sequence data have corroborated the judgment that Sida 


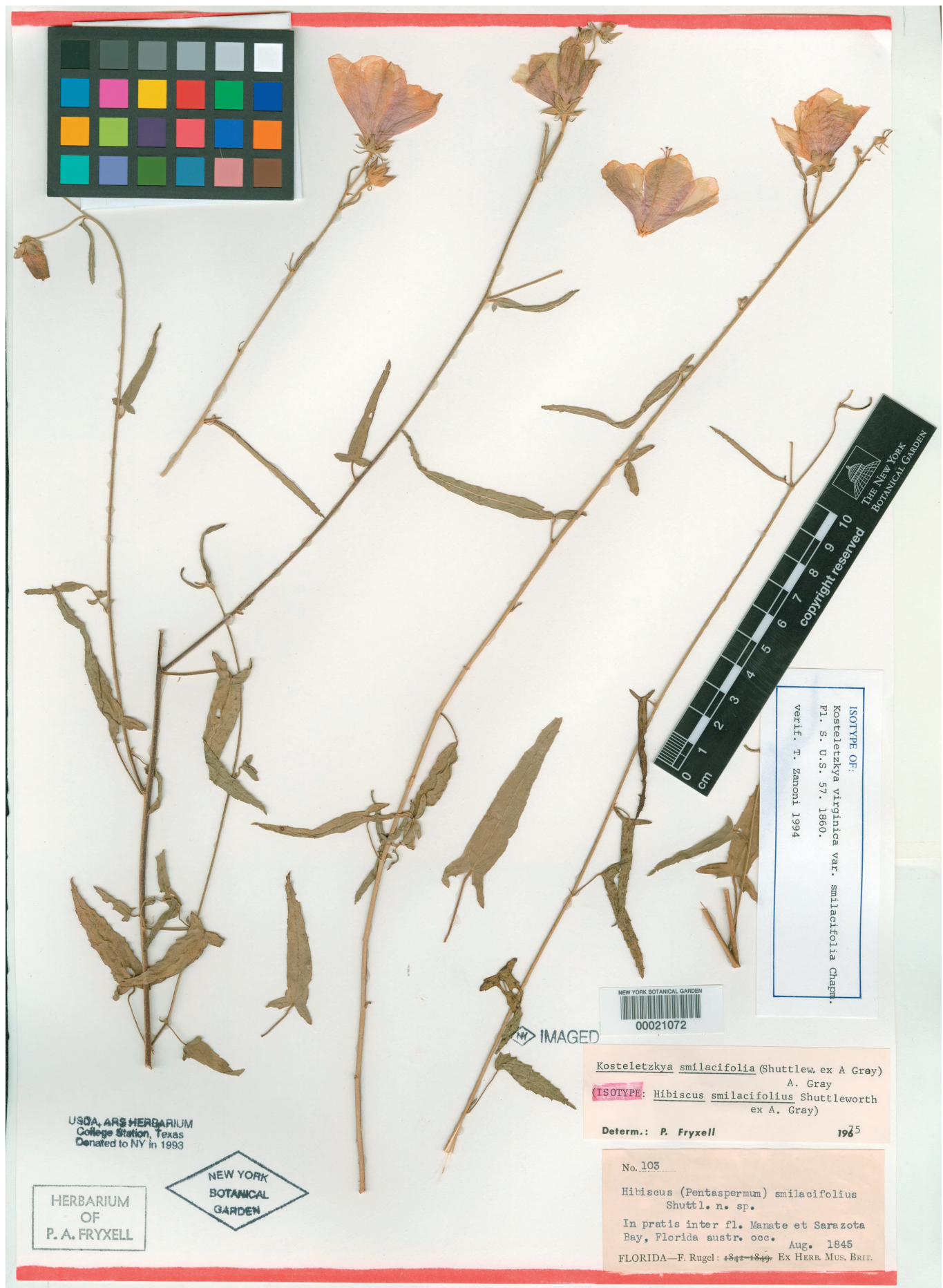

FIG. 7. Lectotype for Kosteletzkya pentacarpos var. smilacifolia (Chapm.) S.N. Alexander. Image courtesy of the C. V. Starr Virtual Herbarium of The New York Botanical Garden, http://sweetgum.nybg.org/science/vh/. 
hermaphrodita is isolated and is not closely related to the core of the genus Sida (Fuertes Aguilar et al. 2003; Tate et al. 2005). Sida hermaphrodita is inferred as either sister to S. hookeriana Miquel and basal to the Plagianthus alliance or sister to the bulk of the Plagianthus alliance and unresolved with S. hookeriana and Lawrencia Hook. (depending on method of analysis). The only remaining taxon that holds a more basal positon than these is Sidasodes columbiana Fryxell \& Fuertes (Fuertes Aguilar et al. 2003; Tate et al. 2005). It is clear from these studies that $S$. hermaphrodita is distantly related to the pantropical Sida "core" clade which apparently includes the type of Sida, Sida alnifolia L.

Sida hermaphrodita can reasonably remain in Sida only if dozens of currently recognized genera were lumped into Sida, creating a massive, hodgpodge, and incoherent genus; there seems no appetite for that course. Alternatively, S. hermaphrodita could be grouped generically with one or more taxa that seem to be its closest relatives based on molecular phylogenies: Sida hookeriana Miq., Sidasodes Fryxell \& Fuertes, Lawrencia Hook., Plagianthus J.R. Forst. \& G. Forst., Hoheria A. Cunn., Asterotrichion Klotzsch, and Gynatrix Alefeld. Most of these genera are trees or shrubs of Oceania, and are clearly not congeneric with S. hermaphrodita on morphological or biogeographic grounds. Sida hermaphrodita might be most plausibly grouped with the neotropical shrub genus Sidasodes, but even if they prove to be sister, they seem too incoherent in gross and fine morphology and biogeography to be regarded as congeneric.

We therefore choose to treat Sida hermaphrodita as a monotypic, isolated, North American temperate genus.

Ripariosida Weakley \& D.B. Poind., gen. nov. TYPE SPECIES: U.S.A. Ripariosida hermaphrodita (L.) Weakley \& D.B. Poind. BasIonym: Napaea hermaphrodita L., Sp. Pl. 2:686. 1753. Other synonyms: Sida hermaphrodita (L.) Rusby.

Description.-Robust perennial herbs to $5 \mathrm{~m}$ tall. Stems erect, minutely stellate-hairy to glabrate. Leaves palmately 5-7-lobed, base cordate, margins serrate, apex long-acuminate, surfaces glabrous. Inflorescence axillary, subumbellate, 2-10-flowered pedunculate corymbs, forming terminal panicles. Calyx cupuliform, ecostulate, lobes wide-triangular; petals white, 8-10 mm; staminal column hairy. Style branched; schizocarps subconic, comprised of 8(-10) mericarps, not reticulate, apex beaked. A monotypic genus, native to temperate, eastern United States.

Etymology.- "Ripario-," referring to its primary natural habitat in river floodplains, + Sida, the genus in which it has awkwardly resided for more than a century.

Ripariosida hermaphrodita (L.) Weakley \& D.B. Poind., comb. nov. BAsIonym: Napaea hermaphrodita L., Sp. Pl. 2:686. 1753. Lectotype: U.S.A. "Habitat in Virginia," Herb. Linn. No. 1203-1. Other synonyms: Sida hermaphrodita (L.) Rusby. Sida napaea Cav. 1788, nom. illegit.

\section{NARTHECIACEAE}

NARTHECIUM: Re-recognition of Narthecium montanum, an (apparently) extinct relict in the North Carolina mountains

Narthecium Hudson 1762 is a genus of about 8-10 species, many narrow disjuncts, collectively with a very fragmented and apparently relictual distribution in the temperate Northern Hemisphere. The type (and firstnamed) species of the genus is Narthecium ossifragum (L.) Hudson, occurring in moist, northern and/or montane portions of Europe. As botanical exploration continued, material belonging to the genus was discovered in additional, widely disjunct portions of the Northern Hemisphere: Corsica, northeastern United States (southern New Jersey and Delaware), northwestern United States (northern California and southwestern Oregon), Blue Ridge Mountains of SEUS (western North Carolina), Coastal Plain of the SEUS (eastern South Carolina), Japan, Balkan Europe, and the Caucasus.

Populations of Narthecium from these disjunct areas were generally recognized as species distinct from the northern European N. ossifragum, as follows (in order of their naming at the species level): N. ossifragum (L.) Hudson 1762, N. americanum Ker-Gawl. 1812 (New Jersey and Delaware), N. asiaticum Maxim. 1867 (Japan), N. californicum Baker 1877 (California and Oregon), N. reverchonii Čelak. 1887 (mountains of Corsica), N. balansae Briq. 1901 (Caucasus). Narthecium scardicum Kosanin 1913 (mountains of Balkan Europe), N. caucasicum Miscz. 1912 (Caucasus), and Abama montana Small 1924 (Blue Ridge Mountains of western North Carolina). 
However, some authors regarded the morphological differences between these taxa as so subtle that varietal status was warranted, despite the disjunct distribution. For instance, Asa Gray treated N. americanum as N. ossifragum var. americanum A. Gray 1867, and N. californicum as N. ossifragum var. occidentalis A. Gray 1868.

In eastern North America, the discovery of Narthecium in a bog in southwestern North Carolina led to John K. Small's naming (in Abama Adanson) of a second eastern North American species, which he contrasted with N. americanum (Small 1924). Later authors of floristic treatments in eastern North America generally did not recognize Small's second species (see, for instance, Radford et al. 1968; Godfrey \& Wooten 1979; Wofford 1989; Zomlefer 1997; Kartesz 1999; Fuse et al. 2012). Unfortunately, none of the authors explained their decision to include Small's second species within the concept of N. americanum, and no monograph of Narthecium, nor any more specific study of the eastern North American material, has been undertaken. It appears that as "taxonomic fashion" turned against Small's "splittiness," this taxon (among many others named by Small) was dismissed without explanation (Weakley 2005).

Small's $(1924,1933)$ decision to consider the NC mountain population a distinct species was founded on its longer, more slender pedicels, larger sepals, petals, and stamens, and smaller capsules. Schumacher (1947), in the most thorough worldwide assessment of Narthecium, agreed, and we also concur, based on an herbarium analysis of the characters of all taxa in the genus.

We borrowed all specimens of Abama/Narthecium from the Carolinas from NY. Included are the two syntypes plus one specimen from Dorchester Co., SC: Summerville, South Carolina. Boggy, 24 Jun 1922, H.W. Trudell s.n. (NY 23946). This last is identified as A. [N.] americana, not A. montana. To compare with these, we examined three of the four N. americanum specimens at NCU (the fourth has a poorly preserved inflorescence), all from NJ.

The two NC specimens have well-developed flowers and some immature fruits. The SC specimen has immature to maturing fruits plus some flowers. Two of the NJ specimens have flowers and immature fruits (collected early-mid-July); the third has fully mature fruits (collected September). In all of these, sepals and petals (= tepals) remain affixed to the plant even in fruit. There is no difference in the length of tepals in flowering vs. fruiting specimens from $\mathrm{NJ}$.

For each specimen, we measured 5 pedicels, tepals, stamens, and capsules to the half millimeter. In some specimens we had to do with less than 5 - for example when stamens or capsules were partly hidden. Narthecium montanum had longer pedicels (mean $=10.0 \mathrm{~mm}$ ) compared to N. asiaticum (mean $=8.0 \mathrm{~mm}$ ), N. californicum (mean $=7.7$ ), or $\mathrm{N}$. americanum (material from NJ and SC, mean $=6.5 \mathrm{~mm}$ ). Narthecium montanum has tepals longer than (mean $=6.6 \mathrm{~mm})$ those of $N$. americanum $($ mean $=5.5 \mathrm{~mm})$ and shorter than $N$. californicum $($ mean $=8.9 \mathrm{~mm})$ and $\mathrm{N}$. asiaticum $($ mean $=7.5 \mathrm{~mm})$. Narthecium montanum has smaller capsules $(\mathrm{mean}=$ 9.3) than $N$. californicum (mean $=10.8 \mathrm{~mm}$ ) or $\mathrm{N}$. americanum (mean $=10.3 \mathrm{~mm}$ ). Narthecium montanum also may differ in leaf width, a character not discussed by Small (1924, 1933): N. montanum leaves $1.6 \mathrm{~mm}$ wide (mean) vs. 2.0 in N. americanum, $3.4 \mathrm{~mm}$ in N. californicum, and $5.0 \mathrm{~mm}$ in N. asiaticum.

While the very few specimens available of $N$. montanum do not allow a statistical analysis, the morphological distinctions in multiple characters, in combination with the geographic disjunction in an area and habitat with high relictual endemism (the Southern Blue Ridge Mountains south of the Asheville Basin; Weakley and Schafale(1994) suggest that concurrence with earlier opinions of Small (1924, 1933), Grey (1938), and Schumacher (1947) of species rank for N. montanum is warranted. Indeed, morphological differences between N. montanum and N. americanum (its geographically nearest congener, and the species with which it has been generally and casually lumped by most floristic authors in the nearly 100 years since its description) are as great or greater as those between most species recognized worldwide in the genus. Considering modern concepts of species, it is a straightforward decision to treat these widely and long separated relict entities at species rank. The following key separates the two eastern North American species of Narthecium (and based on our results, the lone SC Coastal Plain specimen of Narthecium is correctly considered a disjunct, though historic or extirpated, population of N. americanum). 
1. Tepals 4-6 mm long; capsule 10-14 mm long; pedicels stout, ca. $10 \mathrm{~mm}$ long, about as long as the subtending bracts; [plants of Coastal Plain seeps and savannas, extant in s NJ, and historic or extirpated in DE and SC] N. americanum

1. Tepals 6-9 mm long; capsule 8-10 mm long; pedicels slender, mostly 5-8 $\mathrm{mm}$ long, distinctly longer than the subtending bracts; [plants of Southern Blue Ridge, known only and historically from Henderson County, NC]

N. montanum

Narthecium montanum (Small) C.H. Grey, Hardy Bulbs 2:446. 1938. BAsIonym: Abama montana Small, 1924. Specimens: NORTH CAROLINA: Henderson Co.: "Swamps near Flat Rock, NC, F.M. Crayton s.n., July 1919 (NY). "Swamp near Flat Rock, NC," 23 Jul 1919, C.D. Beadle and F.M. Crayton s.n. NY 247780 ["Dear Dr. Small: We are sending you in a box in which you will find the only plant of Abama that we could find in blossom in the low meadow and swamp near Flat Rock, N.C., where the dried specimens recently sent you were gathered. The place is now being pastured by a considerable number of cows-perhaps they contributed to our difficulty in finding more, but it is obviously not plentiful. ... Faithfully yours, C.D. Beadle"]

The "re-recognition" of Narthecium americanum clarifies what is apparently also the extinction of the species. The species has not been seen since its initial collection in July 1919. The French Broad River Bog type (Weakley \& Schafale 1994; Schafale \& Weakley 1990), and Schafale 2012) in which N. montanum occurred has a very interesting set of characteristic species, presenting an interesting mix of narrow endemics and disjuncts of Coastal Plain and/or boreal affinity, including Myrica gale L., Chamaedaphne calyculata (L.) Moench, Gaylussacia orocola (Small) Camp, Helonias bullata L., Juncus caesariensis Coville, Carex collinsii Nutt., C. barrattii Schwein. \& Torr., C. utriculata F. Boott, Xerophyllum asphodeloides (L.) Nutt., Sarracenia purpurea L. var. montana D.E. Schnell \& Determann, Sarracenia jonesii Wherry, and Platanthera integrilabia (Correll) Luer. Weakley \& Schafale (1994) describe the extensive alteration of non-alluvial wetlands (ditching, drainage, conversion to agricultural fields and later industrial plants, suburban developments, roads, golf courses, and an airport) in the immediate area. While it is not impossible that N. montanum will be relocated, known remnant sites of its habitat have been repeatedly surveyed and 98 years after its last sighting hope of its rediscovery seems faint.

Our knowledge that this species ever existed rests on only the flowering collection made by Francis Marion Crayton and a fruiting collection from the same site made a few weeks later by Chauncey Delos Beadle and Crayton, botanists associated with the Biltmore Herbarium. Given the very sparse botanical exploration of the endemic-rich SEUS before extensive land alteration took place, one can only wonder how many species were extirpated prior to discovery (Knapp et al., in prep.).

\section{OROBANCHACEAE}

AGALINIS: Agalinis tenella deleted from the NC flora, with a discussion of its characters

Over the past two decades, attempts to come to an understanding of Agalinis tenella Pennell have met with much frustration, particularly regarding specimens attributed to North Carolina (Carteret, Columbus, Jones, Onslow, Pender, Scotland counties). North Carolina specimens so labeled at NCU and NCSC are inconsistent in critical characters in keys of Pennell $(1929,1935)$ and Weakley (2015), especially in leaf shape and bluntness. In nearly every case, such plants turn out to be A. obtusifolia Raf., as annotated by RJL or BAS. Similarly, many specimens at NCU originally determined as A. tenella from Florida and Alabama have been annotated to A. obtusifolia by Judith Canne-Hilliker or by John Hays, co-authors of the forthcoming treatment of Agalinis for FNA. In their draft treatment for FNA, they state that the range of A. tenella includes Alabama, Florida, Georgia, and South Carolina; they do not credit A. tenella to North Carolina. Weakley (2015) reports a record from Amelia County, in the lower piedmont of VA, which is highly suspect on phytogeographic grounds.

Characters for separating A. tenella are presented in the following key to selected species of the Carolinas, adapted from Weakley (2015).

1. Living plants dull green, usually suffused with much purplish pigment, leaves at least $2 \mathrm{~cm}$ long (but $A$. decemloba with leaves as short as $1.5 \mathrm{~cm}$ ); dried plants darker still, sometimes blackish; dried calyx deep purple, veins obscure, difficult to see even at $10 x$.

2. Upper lip of corolla arched forward over stamens, greatly reducing opening to throat; corolla throat glabrous or glabrate within; Piedmont and Mountains

A. tenuifolia

2. Upper lip of corolla erect or reflexed, throat open; corolla throat densely long hairy within; Coastal Plain and Piedmont.

3. Branches widely spreading or laxly ascending; pedicels at least $4 \times$ length of leaflike bracts; anterior filaments $5-5.5$ $\mathrm{mm}$ long; Coastal Plain from se. SC southwards 
3. Branches ascending to somewhat spreading; pedicels less than $3 \times$ length of leaflike bracts; anterior filaments 7-9 $\mathrm{mm}$; widespread, Coastal Plain and Piedmont

A. setacea

1. Living plants light green or glaucescent, usually with no purplish pigment, leaves less than $1.5(-2.0) \mathrm{cm}$ long; dried plants do not darken but turn pale yellowish green; dried calyx pale yellowish green, veins distinct.

4. Corolla throat within lacking 2 yellow lines; most leaves widen distally to obtuse tips; stem and branches distinctly rough-scabridulous to touch

4. Corolla throat with 2 yellow lines; leaves taper to acute/acuminate tips; stem and branches not or barely scabridulous.

5. Corolla $1.5-2.0 \mathrm{~cm}$ long, its lobes entire to slightly emarginate; Coastal Plain

5. Corolla $1-1.5 \mathrm{~cm}$ long, its lobes usually emarginate or retuse (but sometimes not!); Piedmont and low Mountains, rare in fall-line Sandhills

Critical characters to note in the key are those separating A. tenella from A. obtusifolia: presence of yellow lines in the corolla throat of A. tenella (vs. lacking), leaves with acute tips (vs. obtuse), and stems and branches smooth or smoothish (vs. scabridulous).

One North Carolina specimen of A. tenella is problematic: Carteret County, Musselman 5483 (NCSC). Initially I agreed with Musselman's determination, in part due to his expertise in the genus (e.g., Musselman \& Mann 1978). In 2015 I re-examined Musselman 5483 and annotated it to A. setacea (J.F. Gmel.) Raf. The specimen dried dark brown, without purple or maroon tinges; normally A. setacea has such purple tinges, but not always. The calyces are dark brown with obscure veins as seen without magnification; under a scope veins are obvious but not bold as would be the case in A. obtusifolia and $A$. tenella. The leaves range up to $17 \mathrm{~mm}$ long, on the short side but within the range for A. setacea (I have found that leaf length is variable in A. setacea-more than manuals allow). Leaves are all strongly curved in drying, many curled into semicircles; this is a reliable character that separates specimens of A. setacea from A. obtusifolia and A. tenella. Finally, the gestalt of Musselman 5483 is branchy, almost bushy, as is the case in A. setacea but not in the other species, which are sparingly branched.

Therefore we can now state with confidence that there are no verified A. tenella specimens from North Carolina and that it should be deleted from the flora.

A final note.-In August of 1999, we examined an isotype of A. tenella at GH (Thomas Co. Georgia). The lines and spots in the corolla throat are not well-defined; this is probably attributable to fading over time. Most leaves are acute and more or less uniform in width, but some are clearly broader distally. The stem and branches are scabridulous as in A. obtusifolia, contra Pennell's description. Based on this isotype, our sense is that $A$. tenella is not strongly differentiated from A. obtusifolia, and that the species needs to be reassessed taxonomically.

MELAMPYRUM: A report supporting a broad view of Melampyrum lineare, with no varieties

Recent morphometric study of the hemiparasite Melampyrum lineare Desr. has shown that its four taxonomic varieties, M. lineare var. americanum (Michx.) Beauverd, M. lineare var. latifolium Barton, M. lineare var. lineare, and M. lineare var. pectinatum (Pennell) Fernald, are not sufficiently distinct to warrant recognition (Oldham $\&$ Weeks, in press). Statistical analysis of 45 vegetative, reproductive and ecological characters drawn from 248 herbarium specimens representing the breadth of the species' geographical range revealed that individuals could not be assigned reliably to a named variety on the basis of morphology. Moreover, further analysis of the morphological diversity in this species failed to uncover other groupings of individuals that could support circumscriptions of alternative infraspecific taxa. The conclusion of Oldham \& Weeks (in press) supports the skepticism that Pennell (1935) expressed regarding these infraspecific taxa and the decision by Randle (in press) not to recognize these varieties in the upcoming treatment of this taxon in Flora of North America. Other Melampyrum species—which are entirely Asian or European in distribution-have highly variable phenotypes as well. Authors have suggested this variation may reflect ecotypic or seasonal responses to the abiotic environment (von Soó \& Webb 1972; Štech 2000), although the degree of hemiparasitic connection to and interaction with different host-plant species might also impact morphological development of this species. Untangling the effects of phylogeographic history and ecological variables in controlling the appearance of this polymorphic species awaits further study. 
MYZORRHIZA: Orobanche riparia transferred to Myzorrhiza

The genus Orobanche L. has generally and usually been treated broadly in the last half century, despite the recognition of its internal diversity and a minority opinion that segregate genera should be recognized. Recent critical examinations of Orobanche s.l., based on molecular phylogeny, cytology, morphology, host preference, genome evolution, and biogeography provide clear reasons to split the genus into smaller and more homogeneous clades, treated at either genus rank, section rank, or some mix of those two ranks (Park et al. 2008; Schneeweis et al. 2004a; Schneeweis et al. 2004b; Schneeweis 2013; Schneider et al. 2016; Schneider 2016). Schneider (2016) treats the two American clades at section rank, grouped together in an American genus Aphyllon Mitch., and makes all necessary combinations to formalize that taxonomy. Based on the distinctiveness of the two groups, however, we prefer to accord these two clades generic rank, as Aphyllon Mitch. 1769 and Myzorrhiza Philippi 1858, as recommended by Park et al. (2008), Joel (2009), and Schneeweis (2013).

Three taxa of Myzorrhiza extend into eastern North America, one of which has no available name in Myzorrhiza. We here make only the combinations needed for eastern North America, though additional Myzorrhiza taxa in western North America lack names in that genus.

Myzorrhiza ludoviciana (Nutt.) Rydb. 1903, based on Orobanche ludoviciana Nutt. 1818.

Myzorrhiza multiflora (Nutt.) Rydb. 1906, based on Orobanche multiflora 1848.

Myzorrhiza riparia (L.T. Collins) Weakley, comb. nov. BAsIonym: Orobanche riparia L.T. Collins, J. Bot. Res. Inst. Texas 3:710, f. 1A-B, 2. 2009. Aphyllon riparium (L.T. Collins) A.C. Schneid., PhytoKeys 75:116. Type: U.S.A.: IndiAnA. Gibson Co.: common on bank of slough, ca. $2.5 \mathrm{mi} \mathrm{N}$ of Griffin, 16 Aug 1931, Deam 50941 (ноLотYPE: IND; ISOTYPEs: A, F, GH, IND, MINN, WIS)

The genera can be distinguished with the following key.

1. Flowers solitary on a long pedicel (appearing as a scape, the true stem entirely underground or nearly so); calyx without subtending bracteoles; [native]

1. Flowers several-many, sessile or subsessile in a dense spike; calyx with or without subtending bracteoles; [native or alien].

2. Calyx 5-lobed, the lobes subequal, all well-developed; calyx with subtending bracteoles; [native]

2. Calyx 2-4-lobed, rarely 5-lobed, but then the fifth lobe minute and much smaller than the other lobes; calyx with or without subtending bracteoles; [alien].

3. Calyx divided to the base into 2 lateral halves, these usually 2-lobed, the 4 lobes long-attenuate or caudate; stem unbranched; calyx without subtending bracteoles

3. Calyx tubular, with $4(-5)$ lobes about the length of the calyx tube; stem branched (except in depauperate individuals); calyx with subtending bracteoles

Orobanche Myzorrhiza Phelipanche

\section{POACEAE}

DICHANTHELIUM: Analysis of a W.W. Ashe species of Panicum and its transfer to Dichanthelium sect. Angustifolia

Dichanthelium arenicoloides (Ashe) LeBlond, comb. nov. BAsıonym: Panicum arenicoloides Ashe, J. Elisha Mitchell Sci. Soc. 16:89. 1900. Panicum aciculare Desv. ex Poir. var. arenicoloides (Ashe) Beetle, Phytologia 48:192. 1981. Type: U.S.A. North Carolina: New Hanover Co.: shady sandy woods along the coast near Wilmington, 6 Jun 1899, Ashes.n. (LECTOTYPE, here designated: US 148149).

Additional specimens examined. CUBA. Isla de la Juventud, 13 May 1904, Curtiss 406 (MO). Sierra de Nipe, 11 Aug 1919, Ekman 9701 (NCU). HAITI. 23 Sep 1943, Holdridge 1726 (MO). USA. ALABAMA. Mobile Co.: 1 Aug 1972, Lelong 6679 (NCU). ARKANSAS. Hempstead Co.: 30 Apr 1905, Bush 2522 (NCU). Miller Co.: 9 Jun 1909, Bush 5788 (MO). FLORIDA. Dade Co.: 28 Feb 1918, Small \& Mosier 5587 (MO). Duval Co.: 19 Apr 1897, Churchill s.n. (NCU). Franklin Co.: 1892, Vasey s.n. (DOV). Hillsborough Co.: 4 Dec 1960, Lakela 23654 (NCU). Lake Co.: 1-15 May 1894, Nash 598 (MO). Lee Co.: Jul-Aug 1900, Hitchcock s.n. (MO). Osceola Co.: 14 Oct 1960, Ray 10439 et al. (NCU). Palm Beach Co.: 11 Jun 1979, D. \& S. Boaci 413 (MO). Pasco Co.: 30 Sep 1960, Ray 10316 \& Lakela (NCU). Santa Rosa Co.: 23 May 1966, Freckmann 2228 (MO). Volusia Co.: s.d., Hitchcock 108 (MO). Walton Co.: 17 May 1906, Tracy 9013 (MO). GEORGIA. Gilmer Co.: 20 Jul 1973, Kral 50836 (MO). Grady Co.: 17 Apr 2001, Kral 90823 (MO). Jenkins Co.: s.d., Harper 757 (MO). McIntosh Co.: 15 Oct 1956, Duncan 20647 (NCU). Worth Co.: 17 Aug 1966, Faircloth 3827 (NCU). LOUISIANA. Jefferson Davis Par.: 12 Aug 1928, Tharp s.n. (MO). Orleans Par.: 1868, Nees s.n. (MO). MARYLAND. Allegany Co.: 27 Jun 2005, Knapp 1374 (TAWES). Worcester Co.: 18 Sep 1994, Hirst 707 \& Wilson (DOV). MISSISSIPPI. George Co.: 16 Aug 1952, Jacob 475 (NCU). Hancock Co.: 20 Apr 1969, Rogers 2199-B (MO). Harrison Co.: 3 Aug 1891, Joor s.n. (NCU); 4 Jul 1897, Tracy 3634 (NCU). Jackson Co.: 13 Aug 1953, Demaree 33749 (NCU). Pearl River Co.: 6 May 1964, Sargent 8178 (MO). Winston Co.: 12 Aug 1961, McDaniel 2664 (NCU). NEW JERSEY. Ocean Co.: 12 Jul 1913, Mackenzie 5474 (MO). NORTH CAROLINA. Bladen Co.: 22 Jun 1957, Ahles 29206 \& Haesloop (NCU); 30 Jun 1997, LeBlond 4766 (NCU); 13 Sep 1997, LeBlond 4876 (NCU); 1 Jul 2003, LeBlond 5788 (NCU). Dare Co.: 30 Jul 1959, Schallert 5023 (NCU); 11 Jul 2012, Sorrie 13036 (NCU); 22 May 2014, CVS 142-10- 
1648 (NCU); 29 May 2014, CVS 142-10-1658 (NCU); 31 May 2014, CVS 142-10-1660 (NCU). Hyde Co.: 24 Nov 2004, LeBlond 6079 (NCU); 4 Jul 2005, LeBlond 6079 (NCU); 17 Oct 2005, LeBlond 6157 (NCU). Jones Co.: 17 Jun 1992, LeBlond 2816 (NCU). Onslow Co.: 15 May 1990 , LeBlond 1292 (NCU). Orange Co.: May 1897, Ashe 2033 (NCU). SOUTH CAROLINA. Beaufort Co.: 2 May 1917, Chlurchill s.n. (MO); 27 Jun 1956, Ahles $15545 \&$ Bell (NCU). Charlestown Co.: 20 May 1957, Ahles 25694 \& Haesloop (NCU); 16 Jul 1992, Hill 23735 (MO). Chesterfield Co.: 20 May 1977, Castrale 365 (USCH). Georgetown Co.: 13 Jun 1957, Radford 24946 (NCU); 14 Jul 1970, Stalter 70357 (USCH); 30 Oct 1990 , Nelson 9786 (USCH). Horry Co.: 1 Oct 1957, Duke 0254 (NCU). Jasper Co.: 26 Apr 1988, Batson s.n. (USCH). Lexington Co.: 19 Jun 1961, Henry 610054 (USCH). TENNESSEE. Roane Co.: 9 Oct 1966, S. Furr, J. Furr \& Rogers s.n. (NCU). TEXAS. Angelina Co.: 7 May 1903, Reverchon 4136B (MO). Dallas Co.: May 1883, Reverchon 2365 (MO). Hardin Co.: 10 May 1973, Gould 14239 et al. (MO). Harris Co.: 1899, Eggert s.n. (MO). Smith Co.: 15 May 1902, Reverchon 3535 (MO). Van Zandt Co.: 13 May 1903, Reverchon 4137 (MO). Walker Co.: 18 Apr 1918, Palmer 13376 (MO). Waller Co.: s.d., Hall 9790 No. 834 (MO). VIRGINIA. Suffolk Co.: 27 Jun 1963, Ahles 58160 et al. (NCU).

The only known type specimen for the basionym Panicum arenicoloides is US 148149, which has been treated as an isotype. It contains both a fragment and a photo of the holotype that was in Ashe's personal herbarium. The holotype has not been relocated, and the isotype is here designated as the lectotype. Hitchcock \& Chase (1910) included Panicum orthophyllum Ashe as a synonym of $P$. arenicoloides, but that collection belongs to another taxon, D. filiramum (Ashe) LeBlond. The only known extant type specimen for the name, Panicum orthophyllum, is also in need of lectotypification, and that is provided in a short note elsewhere in this paper.

Panicum arenicoloides was recognized by Hitchcock \& Chase (1910, 1915, 1950), Small (1933), and Silveus (1942), but ignored altogether by Radford, Ahles \& Bell (1968). In more recent treatments it has been placed in synonymy with Dichanthelium aciculare (Gould \& Clark 1978; Wunderlin \& Hansen 2011; Clewell 1985; Hansen \& Wunderlin 1988; Kartesz 1999), and D. aciculare ssp. angustifolium (Elliott) Freckmann \& Lelong (Freckmann \& Lelong 2003). Zuloaga et al. (1993) recognized Beetle's varietal name, P. aciculare var. arenicoloides, but included P. angustifolium Elliott and P. neuranthum Grisebach var. ramosum (=P. fusiforme A. Hitchcock) within it.

Certain vegetative and fruiting characters of Dichanthelium arenicoloides overlap those of D. aciculare sensu stricto and D. angustifolium (Elliott) Gould. Striking features of the D. arenicoloides autumnal spikelets are similar to those of D. fusiforme (A. Hitchcock) Harvill. These character similarities may have contributed to the decision by Gould \& Clark and others to treat the group as a single broadly circumscribed taxon, D. aciculare sensu lato.Vernal leaf length in D. arenicoloides is intermediate to that of D. aciculare and D. angustifolium, but $D$. arenicoloides leaves are on average narrower relative to length, mostly $>20 \times$ as long as wide, while those in D. aciculare and D. angustifolium on average are $<20 \times$ as long as wide. Dichanthelium arenicoloides spikelet length also overlaps that of D. aciculare and D. angustifolium, but unlike the latter two, there are distinct differences between the vernal and autumnal spikelets in $D$. arenicoloides.

Dichanthelium arenicoloides readily separates itself from the others in its autumnal spikelets. Unlike $D$. aciculare and D. angustifolium, and its own vernal spikelets, D. arenicoloides autumnal spikelets are basally attenuate, with the glumes attached $0.3-0.5 \mathrm{~mm}$ below the expansion of the sterile lemma. This is similar to the vernal and autumnal spikelets of $D$. fusiforme. The autumnal spikelets of $D$. fusiforme are 3.5-3.8 mm long while those of D. arenicoloides are 2.3-3.1 mm long.

Dichanthelium arenicoloides is primarily found on the Atlantic and Gulf Coastal Plain from New Jersey to east Texas. There are a few locations in the mountains of Georgia, Maryland, and Tennessee, and the Piedmont of North Carolina. It is also known from the West Indies and Central America. It prefers open sandy soil of pinelands and coastal dunes. In dune areas, the autumnal form has been observed to grow circular mats of \pm prostrate culms, and it may do this in other areas as well.

A key to all North American members of section Angustifolia recognized by LeBlond (2016) is provided here. It includes the recent new combination Dichanthelium filiramum (Ashe) LeBlond and the very rare D. hirstii (Swallen) Kartesz.

1. Vegetative parts glabrous (lowest internodes and sheaths sometimes sparsely pubescent, blades and sheaths sometimes ciliate); mature panicles usually half or less as wide as long; autumnal blades averaging more than half as long as vernal blades.

2. Larger vernal blades $5-14 \mathrm{~cm}$ long and $3-5.5 \mathrm{~mm}$ wide; panicle $<1 / 8$ as wide as long; spikelets $1.8-2.1 \mathrm{~mm}$ long, glabrous, blunt; autumnal blades flat, the larger to $7(-9) \mathrm{mm}$ wide 
2. Larger vernal blades $5-9 \mathrm{~cm}$ long, $2-5 \mathrm{~mm}$ wide; panicle $<1 / 4$ to $1 \frac{1}{2}$ as wide as long; spikelets $1.8-3.0 \mathrm{~mm}$ long, pubescent to glabrous (if glabrous, then spikelets $2.2-3.0 \mathrm{~mm}$ long in D. pinetorum), blunt or pointed; autumnal blades involute, no wider than vernal blades.

3. Larger vernal blades $5-8 \mathrm{~cm}$ long and 3-5 $\mathrm{mm}$ wide; vernal panicles usually less than $1 / 4$ as wide as long, the spikelets often subsecund along the strongly ascending to erect branches; spikelets $1.8-2.2 \mathrm{~mm}$ long, the second glume and sterile lemma summits blunt, about equaling fertile lemma, pubescent; plants of coastal wetlands and Piedmont prairies from NC and AR south to the West Indies and Central America

D. neuranthum

3. Larger vernal blades $5-9 \mathrm{~cm}$ long and $2-3 \mathrm{~mm}$ wide; vernal panicles usually $1 / 4$ to $1 / 2$ as wide as long, the branches ascending; spikelets 2.3-3.0 mm long, the second glume and sterile lemma summits pointed, exceeding fertile lemma, sparsely pubescent to glabrous; plants of s FL

1. Vegetative parts pubescent, at least in the lower portion of plant; mature panicles usually more than half as wide as long; autumnal blades averaging half or less as long as vernal blades (or more than half as long in D. angustifolium with vernal panicles nearly as wide as long).

4. Nodes bearded with spreading or ascending hairs; ligules (1-)1.5-2(-2.5) mm long; blade surfaces usually hirsute; autumnal blades usually flat; spikelets $1.7-2.0(-2.3) \mathrm{mm}$ long

D. pinetorum

4. Nodes bearded or not; ligules to $1 \mathrm{~mm}$ long, mostly less; blade surfaces villous, sparsely pubescent, or glabrous; autumnal blades flat or involute; spikelets $1.8-3.8 \mathrm{~mm}$ long.

5. Nodes bearded with spreading hairs; internodes and sheaths pilose to villous; larger blades 5-8 mm wide, strongly longitudinally wrinkled, both surfaces villous (rarely sparsely villous on the adaxial surface); autumnal blades flat

D. consanguineum

5. Nodes bearded with ascending hairs, or beardless, short-pubescent, or glabrous; lower internodes and sheaths sparsely pilose to villous, the upper often glabrous; larger blades 2-8 mm wide, longitudinally wrinkled or not, the adaxial surface usually glabrous or sparsely pubescent; autumnal blades flat or involute.

6. Spikelets (3.0-)3.2-3.8 mm long, fusiform, pointed at summit, attenuate at base, with both glumes attached 0.3-0.5 mm below expansion of sterile lemma, the autumnal spikelets 3.5-3.8 mm long; larger vernal blades 3-6 $\mathrm{mm}$ wide, the lower and mid-culm blades of similar width; autumnal blades involute

6. Spikelets 1.8-3.1 mm long, obovate, blunt, and the base not attenuate except in autumnal spikelets of $D$. arenicoloides, which are 2.3-3.1 $\mathrm{mm}$ long; larger vernal blades 2-8 $\mathrm{mm}$ wide, the lower usually wider and often shorter than mid-culm blades; autumnal blades involute or flat.

7. Larger vernal blades $8-16 \mathrm{~cm}$ long by $4-8 \mathrm{~mm}$ wide, the lower glabrous to sparsely hairy; vernal and autumnal spikelets 2.3-3.1 mm long; glume attachment $<0.2 \mathrm{~mm}$ below expansion sterile lemma; autumnal blades flat, the larger 2-4 mm wide

7. Larger vernal blades $4-12 \mathrm{~cm}$ long $\times 2-5 \mathrm{~mm}$ wide, the lower glabrous to softly villous; vernal and autumnal spikelets various; glume attachment various; autumnal blades usually involute, to $1.5 \mathrm{~mm}$ wide.

8. Larger vernal blades $4-6(-8) \mathrm{cm}$ long by $2-5 \mathrm{~mm}$ wide, mostly $<$ than $20 \times$ as long as wide, the lower glabrous to sparsely pilose; vernal and autumnal spikelets $1.7-2.3 \mathrm{~mm}$ long; most autumnal spikelets not basally attenuate, their first glumes $0.6-0.9 \mathrm{~mm}$ long; most glumes attached $<0.3 \mathrm{~mm}$ below expansion of sterile lemma; larger autumnal blades to $3 \mathrm{~cm}$ by $1 \mathrm{~mm}$

8. Larger vernal blades $7-12 \mathrm{~cm}$ long by $3-4(-5) \mathrm{mm}$ wide, averaging $>20 \times$ as long as wide, the lower usually softly villous abaxially, and glabrous to sparsely villous adaxially; vernal spikelets $2.1-2.8 \mathrm{~mm}$ long, not basally attenuate, their first glumes $0.7-1.1 \mathrm{~mm}$ long; autumnal spikelets $2.3-3.1 \mathrm{~mm}$ long, most basally attenuate, their first glumes to $1.5 \mathrm{~mm}$ long; glumes of most autumnal spikelets attached $0.3-0.5 \mathrm{~mm}$ below expansion of sterile lemma; larger autumnal blades to $6 \mathrm{~cm}$ by $1.5 \mathrm{~mm}$

D. arenicoloides

DICHANTHELIUM: Lectotypification and taxonomic disposition of Panicum orthophyllum Ashe

During an examination of Panicum (Poaceae) synonymy, it was determined that the extant type specimen for the name P. orthophyllum Ashe is in need of lectotypification, which is here provided. Lectotypification is the designation of a specimen as the substitute for a holotype by a later worker when the nomenclatorial author either failed to designate a valid specimen as holotype, or the designated holotype is missing. In this instance, the designated holotype is missing.

In the following discussion, slashes (/) indicate line breaks in data from labels.

Panicum orthophyllum Ashe, J. Elisha Mitchell Sci. Soc. 16:90. 1900.

Protologue typification: "Shady slopes of sandhills, New Hanover county [sic], N.C., June 1899."

Type specimen determination by Hitchcock \& Chase (1910, p. 173): "The type, in Ashe's herbarium, consists of a small tuft of vernal culms beginning to branch, about $60 \mathrm{~cm}$. high, the lower nodes geniculate. The primary panicles are mostly devoid of spikelets, the secondary nearly mature; the spikelets are $2.2 \mathrm{~mm}$. long."

Types: LECTOTYPE: US 2808981! (fragm., photo of holotype). Lectotype hereby designated. Label data (in A. Chase handwriting): "from type of Panicum orthophyllum Ashe, Wilmington N.C./W.W. Ashe June 7, 1899."

Typification commentary: US 2808981 consists of a photograph of the missing Ashe holotype, and two 
packets containing fragments of material from the holotype. The holotype label in the photograph reads: "type [in Chase handwriting] / HERBARIUM OF W.W. ASHE. / Panicum orthophyllum / Sand hills near Wilmington N.C. / June 7, 1899 [in Ashe's handwriting]." The specimen has been treated as an isotype. It was annotated to Dichanthelium aciculare (Desv. ex Poir.) Gould \& C.A. Clark by Gould \& Clark in 1977, with the notation: "from HOLOTYPE: P. orthophyllum Ashe."

Taxonomic treatment by Hitchcock \& Chase (1910): Synonym of Panicum arenicoloides Ashe.

Current treatment: After examining the lectotype fragments and photograph, I have determined that $P$. orthophyllum belongs to Dichanthelium filiramum (Ashe) LeBlond (basionym P. filiramum Ashe). The salient features are the length of hairs of the ligule (to $2 \mathrm{~mm}$ ) on a leaf fragment, and the bearded nodes as seen in the photo. The overall floral and vegetative characters place the fragments and photographed specimen within the group of taxa recognized as sect. Angustifolia.

DICHANTHELIUM: Analysis of Panicum roanokense Ashe, its recognition at species rank, and transfer at that rank to Dichanthelium

Dichanthelium roanokense (Ashe) LeBlond, comb. nov. BAsIonym: Panicum roanokense Ashe, J. Elisha Mitchell Sci. Soc., 15:44. 1898. Panicum dichotomum L. var. roanokense (Ashe) Lelong, Brittonia 36:265. 1984. Dichanthelium dichotomum ssp. roanokense (Ashe) Freckmann \& Lelong, Sida 20:170. 2002. North Carolina: Dare Co.: dry soil, Roanoke Island, Jun 1898, Ashe s.n. (holotype: NCU 17962; ISOTYPE: NCU 17963. PARATyPes: NCU 24095, 356878; US 970167.)

It is in the autumnal form that the distinctiveness of Dichanthelium roanokense stands out against the vernally similar D. dichotomum (L.) Gould var. dichotomum. The autumnal form of the latter is densely bushy-fascicled, often producing one large mass of clustered leaves. In D. roanokense, the fascicles are smaller and more remote, a condition that is even more pronounced in the similar D. caerulescens (Hackel ex A. Hitchcock) Correll.

The vernal forms of Dichanthelium roanokense and D. dichotomum var. dichotomum are very similar in habit, glabrosity, and spikelet features. (Spikelets are 1.7-2.2 mm long for both taxa, although Freckmann and Lelong (2003) give a spikelet length of $1.5-1.8 \mathrm{~mm}$ for D. roanokense.) The two taxa are most readily separated in the vernal form by leaf orientation and habitat. The blades of $D$. roanokense are usually stiffly erect, while those of var. dichotomum are usually spreading to deflexed (these features are not consistent). Dichanthelium roanokense is most frequently found in wet pine savannas and open swamps, while var. dichotomum is primarily a plant of wet-mesic to dry woodlands and thickets.

There is another character that shows promise in separating the vernal form of these two taxa, but it has not yet been tested rangewide. An examination of specimens at NCU shows a character divergence in the scabrosity of the vernal panicle. In increasing order, the rachis, branches, and pedicels in D. roanokense are moderately to strongly scabrous, especially distally. Those panicle structures in var. dichotomum are generally smooth to weakly scabrous, with the scabrosity often restricted to the pedicels. So far, this character is less distinct in the autumnal form, but is not needed there.

ELYMUS: A new variety of bottlebrush grass, Elymus hystrix, from the Piedmont of eastern North America Members of this genus have a long-standing reputation for hybridization and introgression between species and even genera, leading to obstacles in taxonomic recognition. Coincidentally, these tendencies have also been postulated as the cause for diversity in the genus (Barkworth et. al 2007). With this in mind, we are here considering Elymus hystrix L., a widespread species of eastern North America. Its widely spreading spikelets with reduced to obsolete glumes have often been characters of taxonomic focus, leading in part to its various placement in different genera (e.g., Asperella, Hordeum, Hystrix, Gymnostichum, Zeocriton). A remarkable morphotype occurring primarily in the Carolina Piedmont of the SEUS (and sporadically west) seems to warrant taxonomic recognition based upon the consistent presence of long ([13-]15-25[-27] mm), subequal paired glumes throughout the spike (Fig. 8). Barkworth et. al. (2007) suggested that glume length is generally plastic and most likely attributed to introgression. The authors further noted that E. hystrix is known to hybridize with other species and hypothesized that this long-glumed entity was most likely due to hybridization with Elymus glabriflorus (Vasey ex L.H. Dewey) Scribner \& C.R. Ball. We argue that the characteristic presence of 
this form in the NC Piedmont at the very least reflects a local stabilization of a unique genotype (even if hybridderived). Likewise, though occasional long-glumed specimens can be found throughout the range of the species, this particular form is not locally dominant, despite the sympatry of both E. glabriflorus and E. hystrix elsewhere in the eastern United States. Other taxa that have been treated as varieties of E. hystrix include E. hystrix L. var. bigelovianus (Fernald) Bowden, known from the high elevations of the southern Appalachians and centered in northeastern North America, differing from the typical variety in the presence of pubescent lemmas. Zhang et al. (2010) studied morphological variation in three "types" of Elymus hystrix (not including North Carolina populations), and found reproductive barriers to be weak between the three and concluded that morphological diversity was intraspecific in nature. Due to the unique morphology of the Carolina piedmont populations and their geographic congruence (the typical form of the species occurs widely throughout the state, including the NC Piedmont), we here use taxonomy to reflect a biologically significant phenomenon and subsequently create a novel variety to accommodate this. We also tentatively include those sporadic individuals with consistent long glumes, but occurring outside the range of the primary population within this infraspecific concept. Additional study is needed to determine its origin and relationship to other components of E. hystrix.

Elymus hystrix L. var. piedmontanus D.B. Poind. \& Weakley, var. nov. Type: U.S.A. North CARolina. Chatham Co.: New Hope Creek near Farrington, 10 Jun 1968, S.W. Leonard 1636 (ноцотYPE: NCU!).

Diagnosis.-Differing from Elymus hystrix var. bigelovianus in its lack of pubescent lemmas, and from both this and the typical variety in the possession of consistently long (usually greater than $15 \mathrm{~mm}$ ), paired subequal glumes at nearly all nodes of the inflorescence.

Etymology.-The name "piedmontanus" is used here to emphasize its primary physiographic affinities.

Description.-So far as is known, similar to Elymus hystrix var. hystrix, as reflected in FNA (Barkworth et al. 2007) with the exception of regularly occurring elongate, subequal glumes.

\section{RANUNCULACEAE}

CLEMATIS: Validation of Clematis morefieldii

Clematis morefieldii was described and named by Robert Kral from northern Alabama in 1987. He named the new entity in honor of James D. Morefield, who first provided specimens for examination from collections made on the lower calcareous woodland slopes of the western side of Round Top Mountain in Madison County. In his publication, Kral assigned C. morefieldii to the "subsection Viornae" [sect. Viorna (Persoon) Prantl]. This section of the genus in the SEUS seems to contain several narrow ranging endemics, some of which have been recently named while several others are still in prep. or in ed. (Estes 2006; Floden 2013; Estes pers. comm.).

Due to the extreme rarity of the species, C. morefieldii was listed as Endangered in 1992 by the U.S. Fish and Wildlife Service only five years after the original publication of the species (USFWS 1992). At the time of listing, only five populations were known, all of these in Madison County. Since that time, C. morefieldii has been discovered in adjacent Jackson County, Alabama (Keener et al. 2017), as well as nearby southeastern Tennessee counties, Franklin and Grundy (Estes \& Fleming 2006; Kartesz 2017), and Walker County, Georgia (Estes pers. comm.), but still appears to be a distinct species of very narrow endemic distribution and high imperilment. The morphological basis for the distinction Clematis morefieldii as a new taxon seems to be clearly justifiable and has never been questioned by researchers who work in the geographic region or the taxonomic genus.

However, a recent close re-examination of Kral's original publication revealed a potential nomenclatural issue requiring attention. Kral cited two distinct gatherings of the type material, both from the same locality. In the type citation, he provided a detailed habitat-locality after which he stated the following: "17 Jun 1983, R. Kral 70176 (fruiting material from the same locality, 27 Jun 1986, R. Kral with J.R. Carter 73540). Unfortunately, Kral's citation of specimens from multiple gatherings makes the name Clematis morefieldii invalid (or at least possibly so) based on the requirement that the type be of a single gathering, set forth in the Melbourne Code Art. 8.2 and the consequence of invalidation in Art. 40.2 (McNeill et al. 2012). 


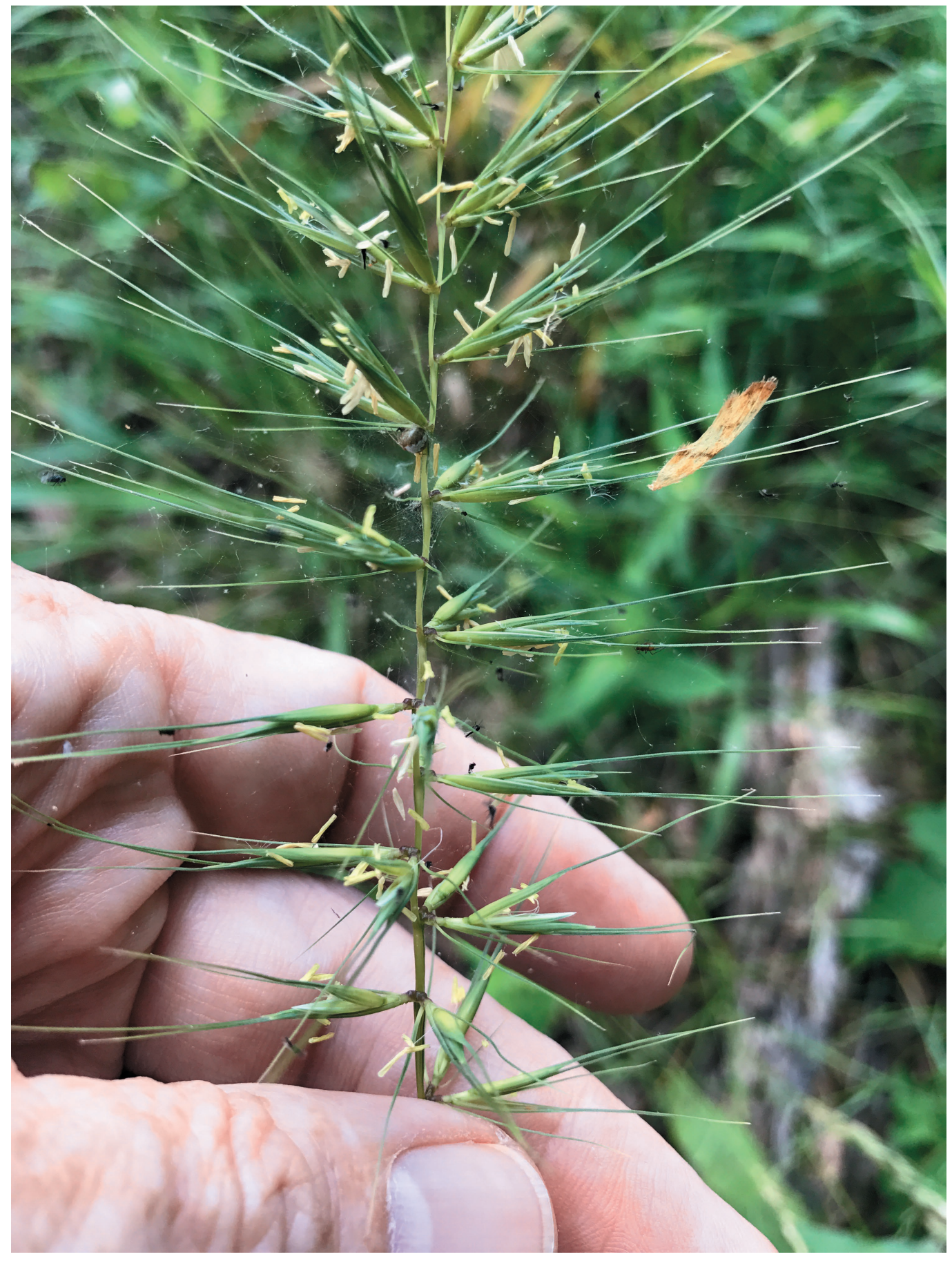

FiG. 8. Elymus hystrix var. piedmontanus, Caswell County, NC, 29 May 2017. Photograph by Alan Weakley. 
Because the name Clematis morefieldii Kral is invalid or may be interpreted to be invalid, we have two options to assure that this distinct species of conservation concern is validly named: 1) provide a newly published name, description, and type or 2) validly publish C. morefieldii by unambiguously citing a type from a single gathering and providing full and direct reference to Kral's previous publication [see Art. 33.1, ex. 2.] (McNeill et al. 2012). For reasons of nomenclatural stability and continuity in conservation efforts, we have decided upon the latter option.

Clematis morefieldii Kral, sp. nov. Type: U.S.A. Alabama. Madison Co.: SE Huntsville, along upslope side of eastward unpaved extension of Deborah Avenue, $0.65 \mathrm{mi}$ SSW of Round Top Mtn., limerocky face of slope, clay soil, in Cotinus-Quercus, vines 2-5 m, sprawling on boulders or shrubs and forest reproduction, calyx greenish with rose tints, 17 Jun 1983, R. Kral 70176 (HOLOTYPE: MO). Note: The original paper by Kral cites isotypes at these institutions: ALU, AUA, BM, CM, DOV, DUR, EKY, F, FLAS, FSU, GA, GH, ILL, ISC, K, LAF, MICH, MISSA, MO, NCU, NY, OS, PAC, RSA, SMU, TENN, TEX, UC, US, VDB, VSC, WAT, WILLI. We are unsure as to whether all or only some of these citations are true isotypes (duplicates of Kral 70176) or may include specimens of Kral 73540 $\&$ Carter. We therefore do not repeat Kral's citation of isotypes, leaving it to the curators at the respective institutions to determine if they have a true isotype ( $\mathrm{Kral} \mathrm{70176)}$ ) or a paratype (Kral $73540 \&$ Carter).

Diagnosis (from Kral).-Perennial scandent vine to $5 \mathrm{~m}$ long. Stems flexuous, copiously villous and/or arachnoid with white hairs. Principal leaves imparipinnate, to $2 \mathrm{dm}$ long, spreading, the rachis base shorter than the lowest leaflets, the rachis axis flexuous, pilosulous or villous; leaflets paired, 9-11, spreading or erect, reduced distally on rachis, the upper 1-3 forming tendrils, the lowest broadly to narrowly ovate, 5-10 cm long, acute to acuminate, mucronulate, thin, entire to 2- or 3-lobate, on pilose petiolules 4-15 mm long; upper surface smooth, yellow-green; lower surface sericeous or pilose. Flowers axillary, solitary or (more often) 1-3(-5) in sessile cymes, the peduncles at anthesis densely white-villous, erect or spreading, 15-25 mm long, with 2 bracteoles at base. Sepals oblong-lanceolate, 20-25 mm long, erect, the tips acuminate, with narrow white borders, slightly spreading to short-reflexed, the backs pink or pale green-and-red, albosericeous, the edges thick, white-tomentulose, the inner surface smooth, longitudinally inconspicuously few-nerved. Stamens linear, 12-20 mm long, the filaments flattened, pilose from middle to apex, the anthers including apiculus 3-3.5 mm long, pilose. Fruit body rhomboidal-ovate, 7-9 mm long, acuminate, compressed, marginally thickened, sericeous, the style $30-35 \mathrm{~mm}$ long, with a brown, plumose coma.

\section{RUSCACEAE OR ASPARAGACEAE S.L.}

MAIANTHEMUM: Evidence for species rank for eastern North American M. racemosum and western North American M. amplexicaule

Maianthemum racemosum (L.) Link in the Flora of North America has been treated as two allopatric subspecies that are morphologically distinguishable using several characters observable in the field and on preserved specimens (LaFrankie 2002, 1986). Recently published molecular phylogenetic analyses of Maianthemum have included only the nominal subspecies (Kim et al. 2017; Meng et al. 2008) or partial chloroplast DNA (cpDNA) of only M. racemosum subsp. amplexicaule (Nutt.) LaFrankie (Kim \& Lee 2007). Of the numerous sequences deposited in Genbank only the trnK intron has been sequenced for both subspecies yet these have not been compared to one another. Samples of the two subspecies are $99 \%$ similar to one another and also to most other Maianthemum species for this highly conserved region. Aaron Floden (unpublished) has sequenced nuclear ribosomal ETS and ITS and the chloroplast petA-psbJ for several samples of both subspecies. Phylogenetic analyses reveal them to be sister taxa, but their molecular divergence from one another is nearly equal to their divergence from M. stellatum. Based on their morphological and molecular differences and their allopatry we suggest that the two are best treated at specific rank. We acknowledge the need for further molecular and cytological work to document the distribution of polyploidy (Kawano \& Iltis 1966) and possible associated molecular variation, especially within the eastern M. racemosum, in which Kim et al. (2017) reveal phylogenetic structure in their analyses.

Maianthemum amplexicaule (Nutt.) W.A. Weber. TYPE: U.S.A.: Hab. in the valleys of the Rocky Mountains, about the sources of the Columbia River, flowering about the middle of Jun 1883, T. Nutt. (LECTOTYPE: GH digital image; IsolECTOTYPE: K digital image).

Although included in Asparagaceae by APG IV (Angiosperm Phylogeny Group 2016), Seberg et al. (2012) and others provide data and interpretations that make a case for the benefits of recognizing smaller families in the Asparagales, a course followed here. 


\section{ACKNOWLEDGMENTS}

We thank Kanchi Gandhi for consultations concerning the Melbourne Code (ICNafp) and how it pertains to matters of validly published names. Reviews of the manuscript by Kanchi Gandhi, Ron Jones, and Guy Nesom substantially improved the paper. We thank the following herbaria for access to specimens via visit, loan, or digital images, and curation of specimens: A, AUA, BRIT, BRY, CLEMS, DOV, DUKE, F, FLAS, FSU, FTG, GA, GH, IBE, IND, JSU, KE, MEM, MICH, MINN, MISS, MO, MUR, NCSC, NCU, NY, TAMU, TAWES, TENN, UARK, UNA, UNCC, US, USCH, UTC, VDB, VSC, US, USCH, USF, USMS, VDB@BRIT, WCUH, WIS, and others. We also thank iNaturalist and citizen-scientist contributors to it for access to images of observations. We thank the Edward Swab Fund for Floristic Botany and the Charles T. Mohr Internship Fund at the UNC Herbarium for support that facilitated these investigations.

\section{REFERENCES}

AleXAnder, E.J. 1941. Two new species from the southern Appalachians. Castanea 6:30-32.

Alexander, S.N., L.C. Hayek, \& A. Weeks. 2012. A subspecific revision of North American saltmarsh mallow, Kosteletzkya pentacarpos (L.) Ledeb. (Malvaceae). Castanea 77:106-122. http://www.bioone.org/doi/full/10.2179/11-022

Aluison, J.R. \& T.E. Stevens. 2001. Vascular flora of Ketona Dolomite outcrops in Bibb County, Alabama. Castanea 66:154-205.

Aluson, J.R. 2011. Synopsis of the Hypericum denticulatum complex (Hypericaceae). Castanea 76:99-115.

Angiosperm Phylogeny Group. 2016. An update of the Angiosperm Phylogeny Group classification for the orders and families of flowering plants: APG IV. Bot. J. Linn. Soc. 181:1-20.

Barkworth, M.E., J.J.N. CAmpbell, \& B. Salomon. 2007. Elymus, modified by Barkworth from Barkworth et al. (eds.), Flora of North America vol. 24, http://herbarium.usu.edu/webmanual on 9 June 2017.

BARNEBY, R.C. 1977. Daleae imagines, an illustrated revision of Errazurizia Philippi, Psorothamnus Rydb., Marina Liebmann, and Dalea Lucanus emend. Barneby, including all species of Leguminosae tribe Amorpheae Borissova ever referred to Dalea. Mem. New York Bot. Gard. 27:1-892.

BARneBY, R.C. 1991. Sensitivae censitae: a description of the genus Mimosa L. (Mimosaceae) in the New World. Mem. New York Bot. Gard. 65:1-835 pp.

BARTGIS, R.L. 1993. The limestone glades and barrens of West Virginia. Castanea 58:69-89.

BeCKMANN, R.L., JR. 1979. Biosystematics of the genus Hydrophyllum L. (Hydrophyllaceae). Canad. J. Bot. 66:1053-1061.

Boraginales Working Group (F. Luebert, L. Cecchi, M.W. Frohlich, M. Gottschling, C.M. Guilliams, K.E. Hasenstab-Lehman, H.H. Hilger, J.S. Miller, M. Mittelbach, M. Nazaire, M. Nepl, D. Nocentinı, D. Ober, R.G. Olmstead, F. Selvi, M.G. Simpson, K. Sutorý, B. Valdés, G.K. WALDEN, \& M. WeIGEND). 2016. Familial classification of the Boraginales. Taxon 65:502-522.

Boudrie, M. \& G. CRemers. 2016. Nomenclatural note on the pteridophyte flora of the Guianas. Amer. Fern J. 106:171-174. Cavanilles, A.J. 1788. Monadelphiae Classis Dissertationes Decem 5:277. Typographia regia, Madrid, Spain.

Celep, F., M. Koyuncu, R.M. Fritsch, A. Kahraman, \& M. DoĞan. 2012. Taxonomic importance of seed morphology in Allium (Amaryllidaceae). Syst. Bot. 37:893-912.

Chol, H.J. \& J.H. CotA-SÁnchez. 2010. A taxonomic revision of Allium (Alliaceae) in the Canadian prairie provinces. Botany 88:787-809.

Clement, I.D. 1957. Studies in Sida (Malvaceae). I. A review of the genus and monograph of the sections Malachroideae, Physalodes, Pseudomalvastrum, Incanifolia, Oligandrae, Pseudonapaea, Hookeria, and Steninda. Contr. Gray Herb. 180. 5-91.

CLEWELL, A.F. 1985. Guide to the vascular plants of the Florida Panhandle. University Presses of Florida, Tallahassee, U.S.A. ConstanCE, L. 1942. The genus Hydrophyllum L. Amer. Midl. Naturalist 27:710-731.

CRUm, H.A. \& L.E. Anderson. 1956. Taxonomic studies on North American mosses. I-V. J. Elisha Mitchell Sci. Soc. 72:276-291.

DeLAney, K., N. Bissett, \& J.D. Weidenhamer. 1999. A new species of Carphephorus (Asteraceae; Eupatorieae) from peninsular Florida. Bot. Explor. 1:1-15.

Duncan, W.H. \& N.E. BritTAin. 1966. The genus Gaylussacia (Ericaceae) in Georgia. Bull. Georgia Acad. Sci. 24:13-26.

Ebihara, A., J.-Y. Dubuisson, K. Iwatsuki, S. Hennequin, \& M. Ito. 2006. A taxonomic revision of Hymenophyllaceae. Blumea $51: 221-280$.

ESTES, D. 2006. A new narrowly endemic species of Clematis (Ranunculaceae: subgenus Viorna) from northeastern Texas. Sida 22:65-77.

Estes, D. \& C. Fleming. 2006. Clematis morefieldii (Ranunculaceae) new to Tennessee. Sida 22:821-824. 
EstilL, J.C. \& M.B. CRuzAn. 2001. Phytogeography of rare plant species endemic to the southeastern United States. Castanea 66(1-2):3-23.

Floden, A.J. 2013. A new leatherflower (Clematis: Ranunculaceae) from the southern Appalachians. J.Bot. Res. Inst. Texas 7(1):1-7.

FERNALD, M.L. 1950. Gray's manual of botany, eighth (centennial) edition. Corrected printing, 1970. D. Van Nostrand Co., New York, N.Y., U.S.A.

FETTER, K.C. 2014. Migration, adaptation, and speciation - a post-glacial history of the population structure, phylogeography, and biodiversity of Liriodendron tulipifera L. (Magnoliaceae). M.S. thesis. University of North Carolina, Chapel Hill, U.S.A.

Floden, A.J. 2015. A new beebalm, Monarda austroappalachiana (Lamiaceae), from the Southern Appalachians. Phytoneuron 2015-28:1-9. Published 29 April 2015. ISSN 2153 733X

Flores-Cruz, M., H.D. Santana-LiRA, S.D. Koch, \& R. Grether. 2004. Taxonomic significance of leaflet anatomy in Mimosa series Quadrivalvis (Leguminosae, Mimosoideae). Syst. Bot. 29:892-902.

Fosberg, F.R. \& L. Artz. 1953. The varieties of Monarda fistulosa L. Castanea 18:128-130.

FreCKMAnn, R.W. \& M.G. Lelong. 2003. Dichanthelium. In: Flora of North America Editorial Committee. 2003a. Flora of North America north of Mexico. Volume 25, Magnoliophyta: Commelinidae (in part): Poaceae, part 2. Oxford Univ. Press, New York, NY, U.S.A. Pp. 406-451.

FrYXELL, P.A. 1985. Sidus sidarum-V. The North and Central American species of Sida. Sida 11:62-91.

FRYXELL, P.A. 1997. The American genera of Malvaceae-II. Brittonia 49:204-269.

Fuertes Aguilar, J., P.A. FryXeLL, \& R.K. JANSEn. 2003. Phylogenetic relationships and classification of the Sida generic alliance (Malvaceae) based on nrDNA ITS evidence. Syst. Bot. 28:352-364.

Fuse, S., N.S. Lee, \& M.N. Tamura. 2012. Biosystematic studies on the family Nartheciaceae (Dioscoreales). I. Phylogenetic relationships, character evolution and taxonomic re-examination. PI. Syst. Evol. 298:1575-1584.

GAISER, L.O. 1946. The genus Liatris. Rhodora 48:165-183, 216-263, 273-326, 331-382, 393-412.

GLEASON, H.A. 1952. The new Britton and Brown illustrated flora of the northeastern United States and adjacent Canada. New York Botanical Garden and Hafner Press, New York, N.Y., U.S.A.

GLEASON, H.A. \& A. CRONQuist. 1991. Manual of vascular plants of northeastern United States and adjacent Canada, second edition. New York Botanical Garden, Bronx, N.Y., U.S.A.

GODFREY, R.K. 1988. Trees, shrubs, and woody vines of northern Florida and adjacent Georgia and Alabama. University of Georgia Press, Athens, Georgia, U.S.A.

Godfrey, R.K. \& J.W. Wooten. 1979. Aquatic and wetland plants of southeastern United States, monocotyledons. University of Georgia Press, Athens, Georgia, U.S.A.

Godfrey, R.K. \& J.W. Wooten. 1981. Aquatic and wetland plants of southeastern United States, dicotyledons. University of Georgia Press, Athens, Georgia, U.S.A.

Gould, F.W. \& C.A. Clark. 1978. Dichanthelium (Poaceae) in the United States and Canada. Ann. Missouri Bot. Gard. 65:1088-1132.

Gray, A. 1849. Plantae Fendlerianie Novi-Mexicanae: an account of a collection of plants made chiefly in the vicinity of Santa Fe, New Mexico, by Augustus Fendler. Mem. Amer. Acad. Arts 4:1-116.

Grether, R. 2000. Nomenclatural changes in the genus Mimosa (Fabaceae, Mimosoideae) in southern Mexico and Central America. Novon 10:29-37.

GREY, C.H. 1938. Hardy bulbs including half hardy bulbs and tuberous and fibrous rooted plants. Vol. 2. Williams \& Norgate, London.

Hansen, B.F. \& R.P. Wunderlin. 1988. Synopsis of Dichanthelium (Poaceae) in Florida. Ann. Missouri Bot. Gard. 75:1637-1657. Hitchсоск, A.S. \& A. Chase. 1910. The North American species of Panicum. Contr. U.S. Natl. Herb. 15:1-396.

Hitchсоск, A.S. \& A. ChASE. 1915. Tropical North American species of Panicum. Contr. U.S. Natl. Herb. 17:459-539.

HitchCock, A.S. \& A. ChASE. 1950. Manual of the grasses of the United States, second edition, revised by A. Chase. U.S.

Department of Agriculture Miscellaneous Publication No. 200. Washington, D.C., U.S.A.

JoEL, D.M. 2009. The new nomenclature of Orobanche and Phelipanche. Weed Research 49 (Suppl. 1):6--7.

Johnson, G.P. 1997. Calycanthaceae. In: Flora of North America Editorial Committee. Flora of North America north of Mexico. Volume 3, Magnoliophyta: Magnoliidae and Hamamelidae. Oxford Univ. Press, New York, NY, U.S.A. Pp. $23-25$.

KARTESZ, J.T. 1999. A synonymized checklist and atlas with biological attributes for the vascular flora of the United States, Canada, and Greenland. First Edition. In: Kartesz, J.T. and C.A. Meacham. Synthesis of the North American flora, version 1.0. North Carolina Botanical Garden, Chapel Hill, North Carolina, U.S.A. 
KARTESZ, J.T. 2017. Floristic synthesis of North America, Version 1.0. Biota of North America (BONAP). (in press).

KAWANO, S. \& H.H. LLIIs. 1966. Cytotaxonmy of the genus Smilacina (Liliaceae) II. Chromosome morphology and evolutionary consideration of New World species. Cytologia 31:12-28.

Keener, B.R., A.R. Diamond, L.J. Davenport, P.G. Davison, S.L. Ginzbarg, C.J. Hansen, C.S. Major, D.D. Spaulding, J.K. Triplett, \& M. Woods. 2017. Alabama plant atlas. [S.M. Landry and K.N. Campbell (original application development), Florida Center for Community Design and Research. University of South Florida]. University of West Alabama, Livingston, U.S.A.

KeEVER, C. 1950. Causes of succession on old fields of the Piedmont, North Carolina. Ecol. Monogr. 20:229-250.

KeEVER, C., H.J. Oosting, \& L.E. AndeRson. 1951. Plant succession on exposed granite of Rocky Face Mountain, Alexander County, North Carolina. Bull. Torrey Bot. Club 78:401-421.

KeEveR, C. 1983. A retrospective view of old-field succession after 35 years. Amer. Midl. Naturalist 110:397-404

KIM, C., K.M. CAmERoN, J.-H. KIM. 2017. Molecular systematics and historical biogeography of Maianthemum s.s. Amer. J. Bot. 104(6):1-14. https://doi.org/10.3732/ajb.1600454

KIM, S.-C. \& N.S. LeE. 2007. Generic delimitation and biogeography of Maianthemum and Smilacina (Ruscaceae sensu lato): preliminary results based on partial 3' matK gene and trnk 3' intron sequences of cpDNA. PI. Syst. Evol. 265:1-12.

KImBalL, R.T., D.J. CRAWFoRd, J.R. PAGE, \& P.J. HARMon. 2001. Inter-simple sequence repeat (ISSR) diversity within Monarda fistulosa var. brevis (Lamiaceae) and divergence between var. brevis and var. fistulosa in West Virginia. Brittonia 53:511-518.

KRAL, R. 1987. A new Viorna Clematis from Northern Alabama. Ann. Missouri Bot. Gard. 74(3):665-669.

LAFrankIE, J.V. 2002. Maianthemum. In: Flora of North America Editorial Committee, eds. Flora of North America north of Mexico. Volume 26, Magnoliophyta: Liliidae: Liliales and Orchidales. Oxford Univ. Press, New York, N.Y., U.S.A. Pp. 206-210.

LAFRANKIE, J.V. 1986. Morphology and taxonomy of the New World species of Maianthemum Liliaceae). J. Arnold Arbor. 67:371-439.

Lara, F., R. Garillett, B. Goffinet, I. Draper, R. Medina, B. Vagalondo, \& V. Mazimpka. 2016. Lewinskya, a new genus to accommodate the phaneroporous and monoicous taxa of Orthotrichum (Bryophyta, Orthotrichaceae). Cryptog. Bryol. 37:361-382.

LEBLond, R.J. 2016. Dichanthelium. In: A.S. Weakley, Flora of the Southern and Mid-Atlantic States. http://www.herbarium.unc.edu/flora.htm.

LINNAEUS, C. 1753. Species plantarum, exhibentes plantas rite cognitas, ad genera relatas, cum differentiis specificis, nominibus trivialibus, synonymis selectis, locis natalibus, secundum systema sexuale digestas. Tomus II. Holmiae, Impensis Laurentii Salvii, Stockholm. Pp. 561-1200.

LUTEYN, J.L. ET AL. 1996. Ericaceae of the southeastern United States. Castanea 61:101-144.

McCoRMICK, J.F. \& R.B. PLATT. 1980. Recovery of an Appalachian forest following the Chestnut Blight or Catherine Keever You were right! Amer. Midl. Naturalist 104:264-273.

McNeaL, D.W. \& T.D. JACOBSEN. 2002. Allium, Flora of North America North of Mexico. 26:224-276. Oxford University Press, New York, U.S.A.

McNeill, J., F.R. Barrie, W.R. Buck, V. Demoulin, W. Greuter, D.L. Hawksworth, P.S. Herendeen, S. Knapp, K. Marhold, J. Prado, W.F. Prud'homme van Reine, G.F. Smith, J.H. Wiersema, \& N.J. Turland (eds.). 2012. International code of nomenclature for algae, fungi, and plants (Melbourne Code): Adopted by the Eighteenth International Botanical Congress Melbourne, Australia, July 2011. Regnum Veg. 154. Koeltz Scientific Books, Königstein, Germany.

Meng, Y., J. Wen, Z.-L. Nie, H. SUn, Y.-P. YAng. 2008. Phylogeny and biogeographic diversification of Maianthemum (Ruscaceae: Polygonatae). Molec. Phylogen. Evol. 49:424-434.

MusseLmAN, L.J. \& W.F. MANN, JR. 1978. Root parasites of southern forests. USDA, Forest Service Gen. Tech. Rpt. SO-20.

Nesom, G.L. 2005. Infrageneric classification of Liatris (Asteraceae: Eupatorieae). Sida 21:1305-1321.

Nesom, G.L. 2006. Liatris. In: Flora of North America Editorial Committee, eds. Flora of North America north of Mexico. Volume 21, Magnoliophyta: Asteridae, part 6: Asteraceae, part 3. Oxford Univ. Press, New York, N.Y., U.S.A. Pp. 512-535.

NicELY, K.A. 1965. A monographic study of the Calycanthaceae. Castanea 30:38-81.

NoyES, R.D. 2006. Intraspecific nuclear ribosomal DNA divergence and reticulation in sexual diploid Erigeron strigosus (Asteraceae). Amer. J. Bot. 93:470-479.

Noyes, R.D. \& D.V. GRofF. 2011. Geography and phylogeny of sexual diploid Erigeron strigosus (Asteraceae) in Arkansas and Missouri. J. Bot. Res. Inst. Texas 5:577-586. 
NoYES, R.D. \& J.D. WAGNER. 2014. Dihaploidy yields diploid apomicts and parthenogens in Erigeron (Asteraceae). Amer. J. Bot. 101:865-874.

Oldham, K.A. \& A. Weeks. In press. Varieties of Melampyrum lineare (Orobanchaceae) revisited. Rhodora 119(979).

Ownbey, M. \& H.C. AASE. 1956. Cytotaxonomic studies in Allium. I. The Allium canadense alliance. Res. Stud. State College Washington, Monogr. Suppl. 1:1-106.

OwnBEy, M. \& H.C. Aase. 1959. Allium speculae, a new species of the Allium canadense alliance from Alabama. Rhodora 61:70-72.

PennelL, F.W. 1929. Agalinis and allies in North America - II. Proc. Acad. Natl. Sci. Phila. 81:111-248.

Pennell, F.W. 1935. The Scrophulariaceae of temperate eastern North America. Monogr. Acad. Natl. Sci. Phila. 1:1-650.

Quarterman, E. \& C. Keever. 1962. Southern mixed hardwood forest: Climax in the Southeastern coastal plain. Ecol. Monogr. 32:167-185.

Radford, A.E., H.E. Ahles, \& C.R. Bell. 1968. Manual of the vascular flora of the Carolinas. University of North Carolina Press, Chapel Hill, N.C., U.S.A.

Randle, C.P. In press. Melampyrum Desr. In: Flora of North America Editorial Committee, eds. 1993+. Flora of North America North of Mexico. 19+ vols. New York and Oxford. Vol. 17. New York, NY and Oxford, UK.

RhoAds, A.F. \& T.A. BLock. 2007. The plants of Pennsylvania: an illustrated manual. Second edition. Univ. of Pennsylvania Press, Philadelphia, Pennsylvania, U.S.A.

Committee of the Botanical Club of the American Association for the Advancement of Science. 1894. List of Pteridophyta and Spermatophyta growing without cultivation in northeastern North America. Mem. Torrey Bot. Club 5:1-377.

Schafale, M.P. 2012. Guide to the natural communities of North Carolina, fourth approximation. N.C. Natural Heritage Program, Raleigh, N.C., U.S.A.

Schafale, M.P. \& A.S. Weakley. 1990. Classification of the natural communities of North Carolina, third approximation. N.C. Natural Heritage Program, Raleigh, N.C., U.S.A. http://www.ils.unc.edu/parkproject/nhp/publications/class.pdf

SchiluING, E.E. 2011. Hybrid genera in Liatrinae (Asteraceae: Eupatorieae). Molec. Phylog. Evol. 59:158-167.

Schmidt, G.J. \& E.E. Schiluing. 2000. Phylogeny and biogeography of Eupatorium (Asteraceae: Eupatorieae) based on nuclear ITS sequence data. Amer. J. Bot. 87:716-726.

SchneEWeISS, G.M. 2013. Phylogenetic relationships and evolutionary trends in Orobanchaceae. In: D.M. Joel, J. Gressel J, and L.J. Musselman, eds. Parasitic Orobanchaceae. Berlin Heidelberg: Springer, 243-265. https://doi. org/10.1007/978-3-642-38146-1_14

Schneeweiss G.M., A.E.L. Colwell, J.-M. Park, C.-G. Jang, \& T.F. Stuessy. 2004a. Phylogeny of holoparasistic Orobanche (Orobanchaceae) inferred from nuclear ITS sequences. Molecular Phylogenetics and Evolution 30:465-478. https:// doi.org/10.1016/S1055-7903(03)00210-0

Schneeweiss, G.M., T. Palomeque, A.E.L. Colwell, \& H. Weiss-Schneeweiss. 2004b. Chromosome numbers and karyotype evolution in holoparasitic Orobanche (Orobanchaceae) and related genera. Amer. J. Bot. 91:439-448. https://doi. org/10.3732/ajb.91.3.439

SCHNEIDER, A.C. 2016. Resurrection of the genus Aphyllon for New World broomrapes (Orobanche s.l., Orobanchaceae). PhytoKeys 75:107-118.

Schneider A.C, A.E.L. Colwell, G.M. Schneeweiss, \& B.G. Baldwin. 2016. Cryptic host-specific diversity among western hemisphere broomrapes (Orobanche s.l., Orobanchaceae). Annals Bot. 118:1101-1111. https://doi.org/10.1093/aob/ mcW158

SCHUMACHeR, A. 1947. Die Moorlilien (Narthecium)-Arten Europas. Archiv für Hydrobiologie 41:112-195.

SCORA, R.W. 1967. Interspecific relationships in the genus Monarda (Labiatae). Univ. Calif. Publ. Bot. 41:1-71.

Seberg, O., G. Petersen, J.I. Davis, J.C. Pires, D.W. Stevenson, M.W. Chase, M.F. Fay, D.S. Devey, T. Jørgensen, K.J. Sytsma, \& Y. Pillon. 2012. Phylogeny of the Asparagales based on three plastid and two mitochondrial genes. Amer. J. Bot. 99:875-889.

SILVEUS, W.A. 1942. Grasses: Classification and description of species of Paspalum and Panicum in the United States. Published by the author, San Antonio, Texas, U.S.A.

SMALL, J.K. 1903. Flora of the southeastern United States, being descriptions of the seed-plants, ferns and fern-allies growing naturally in North Carolina, South Carolina, Georgia, Florida, Tennessee, Alabama, Mississippi, Arkansas, Louisiana, and in Oklahoma and Texas east of the one hundredth meridian. Published by the author, New York, N.Y., U.S.A.

SMALL, J.K. 1924. A new bog-asphodel from the mountains. Torreya 24:86-87.

SMALL, J.K. 1933. Manual of the southeastern flora, being descriptions of the seed plants growing naturally in Florida, 
Alabama, Mississippi, eastern Louisiana, Tennessee, North Carolina, South Carolina, and Georgia. University of North Carolina Press, Chapel Hill, North Carolina, U.S.A.

Sorrie, B.A., A.S. Weakley, \& G.C. Tucker. 2009. Gaylussacia. In: Flora of North America Editorial Committee. Flora of North America north of Mexico, volume 8: Magnoliophyta: Paeoniaceae to Ericaceae. Oxford Univ. Press, New York, N.Y., U.S.A.Pp. 530-535

ŠTECH, M. 2000. Seasonal variation in Melampyrum nemorosum. Preslia 72:345-368.

Tate, J.A., J. Fuertes Aguilar, S.J. Wagstaff, J.C. La Duke, T.A. Bodo Slotta, \& B.B. Simpson. 2005. Phylogenetic relationships within the tribe Malveae (Malvaceae, subfamily Malvoideae) as inferred from its sequence data. Amer. J. Bot. 92:584-602.

Tennessee Flora Committee. 2015. Guide to the vascular plants of Tennessee (editors: E.W. Chester, B.E. Wofford, J. Shaw, D. Estes, and D.H. Webb). Univ Tenn. Press, Knoxville, Tennessee, U.S.A.

TURNER, B.L. 1994a. Northern Mexican species of Schrankia (Mimosaceae) transferred to Mimosa. Phytologia 76:421-425.

TURneR, B.L. 1994b. Mimosa rupertiana B.L. Turner, a new name for M. occidentalis (Wooton \& Standley) B.L. Turner, not M. occidentalis Britton \& Rose. Phytologia 77:81-82.

United States Fish and Wildlife Service (USFWS). 1992. Endangered and threatened wildlife and plants; determination of Clematis morefieldii (Morefield's leather flower) to be an endangered species. Fed. Reg. 57(98):21562-34420.

United States Fish and Wildifife Service (USFWS). 2014. Endangered and threatened wildlife and plants; endangered species status for Trichomanes punctatum ssp. floridanum (Florida bristle fern); Proposed Rules. Fed. Register 79 (196):61136-61161.

VITT, D.H. 2014. Orthotrichaceae. In: Flora of North America Editorial Committee, eds. Flora of North America north of Mexico. Volume 28. Bryophyta, part 2. Oxford Univ. Press, New York, N.Y., U.S.A. Pp. 37-82.

von Soó, R. \& D.A. WebB. 1972. Melampyrum L. In: T.G. Tutin, V.H. Heywood, N.A. Burges, D.M. Moore, D.H. Valentine, S.M. Walters, and D.A. Webb, eds. Flora Europaea, Vol. 3. Cambridge University Press, London, U.K. Pp. $253-257$.

WEAKLEY, A.S. 2005. Change over time in our understanding of the flora of the southeastern United States: implications for plant systematics, bioinformatics, and conservation. Ph.D. dissertation, Duke University, Nicholas School of the Environment and Earth Sciences.

WeAKLEY, A.S. 2015. Flora of the Southern and Mid-Atlantic States, May 2015 edition. UNC Herbarium, Chapel Hill, NC 1320 pp. Also online at http://herbarium.unc.edu/flora.htm.

WeAKLEY, A.S. 2017. Flora of the Southern and Mid-Atlantic States, 2017 edition. UNC Herbarium, Chapel Hill, NC. Also online at http://herbarium.unc.edu/flora.htm.

WeAkLEY, A.S. and M.P. Schafale. 1994. Non-alluvial wetlands of the southern Blue Ridge: diversity in a threatened ecosystem. Water, Air Soil Pollut. 77:359-383.

WEAKLEY, A.S., J.C. LUDWIG, \& J.F. TownSEND. 2012. Flora of Virginia. BRIT Press, Fort Worth, Texas, U.S.A.

Weakley, A.S., R.J. LeBlond, B.A. Sorrie, C.T. Witsell, L.D. Estes, K.G. Mathews, A. Ebihara, \& K. Gandhi. 2011. New combinations, rank changes, and nomenclatural and taxonomic comments in the vascular flora of the southeastern United States. J. Bot. Res. Inst. Texas 5:437-455.

WEBER, W.A. 1987. New names and combinations principally in the Rocky Mountain USA Flora VI. Phytologia 62:437-438. Wessels Boer, J.G. 1962. The New World species of Trichomanes sect. Didymoglossum and Microgonium. Acta Bot. Neerl. 11:277-330.

WheELER, E.J. 2011. Phylogenetic and phylogenomic studies of wild onions (Allium, Amaryllidaceae) at three taxonomic scales. Ph.D. dissertation, University of Missouri, U.S.A.

WoLfE, L.M. 1993. Reproductive consequences of a flower color polymorphism in Hydrophyllum appendiculatum. Amer. Midl. Naturalist 129:405-408.

Wunderlin, R.P. \& B.F. HANSEN. 2011. Guide to the vascular plants of Florida, third edition. University Press of Florida, Gainesville, Florida, U.S.A.

WundeRLIn, R.P. \& B.F. HANSEN. 2015. Flora of Florida. Vol. II. Dicotyledons, Cabombaceae through Geraniaceae. University Press of Florida, Gainesville, Florida, U.S.A.

WofFoRd, B.E. 1989. Guide to the vascular plants of the Blue Ridge. Univ. of Georgia Press, Athens, Georgia, U.S.A.

Zhang, H.Q., X. FAN, L.-N. ShA, H.-Y. Kang, X.-L. WANG, \& Y.-H. Zhou. 2010. Morphological variation in Elymus hystrix L. (Poaceae: Triticeae). Caryologia 63(4):359-366.

Zomlefer, W.B. 1997. The genera of Nartheciaceae in the southeastern United States. Harvard Pap. Bot. 2:195-211.

Zuloaga, F.O., R.P. Elus, \& O. Morrone. 1993. A revision of Panicum subg. Dichanthelium sect. Dichanthelium (Poaceae: Panicoideae: Paniceae) in Mesoamerica, the West Indies, and South America. Ann. Missouri Bot. Gard. 80:119-190. 